Review Article

\title{
Natural Products: Review for Their Effects of Anti-HBV
}

\author{
Xuqiang Liu $\mathbb{D},,^{1,2}$ Changyang Ma $\mathbb{D}^{1},{ }^{1}$ Zhenhua Liu $\mathbb{D},{ }^{1}$ and Wenyi Kang $\mathbb{D}^{1,2,3}$ \\ ${ }^{1}$ National R \& D Center for Edible Fungus Processing Technology, Henan University, Kaifeng 475004, China \\ ${ }^{2}$ Functional Food Engineering Technology Research Center, Henan Province, Kaifeng 475004, China \\ ${ }^{3}$ Joint International Research Laboratory of Food \& Medicine Resource Function, Henan University, Kaifeng, \\ 475004 Henan Province, China
}

Correspondence should be addressed to Zhenhua Liu; liuzhenhua623@163.com and Wenyi Kang; kangweny@hotmail.com

Received 10 July 2020; Revised 13 November 2020; Accepted 23 November 2020; Published 10 December 2020

Academic Editor: Abdul Ahad

Copyright (c) 2020 Xuqiang Liu et al. This is an open access article distributed under the Creative Commons Attribution License, which permits unrestricted use, distribution, and reproduction in any medium, provided the original work is properly cited.

\begin{abstract}
Hepatitis B is a global infectious disease, seriously endangering human health. Currently, there are mainly interferons and nucleoside analogues treatment of hepatitis B in the clinic, which have certain therapeutic effects on hepatitis B, but their side effects and drug resistance are increasingly prominent. Therefore, it is urgently needed to discover and develop new anti-HBV drugs, especially natural products, which have novel, high efficiency, and low toxicity anti-HBV compounds with novel antiviral mechanisms. In this manuscript, the natural products (polysaccharides and 165 compounds) with the activity of antihepatitis B virus are discussed according to their chemical classes, including 14 phenylpropanoids, 8 flavonoids, 12 xanthones, 13 anthroquinones, 47 terpenoids, 6 alkaloids, 15 enediynes, 11 aromatics, 18 phenylalanine dipeptides compounds, and 13 others. In addition, the anti-HBV mechanism and targets of natural product were also discussed. The aim of this review is to report new discoveries about anti-HBV natural products and to provide reference for researchers.
\end{abstract}

\section{Introduction}

Viral hepatitis B, referred to as hepatitis B, is a disease caused by the infection of hepatitis B virus (HBV, Figure 1). The infection of HBV can cause liver failure, acute or chronic hepatitis, cirrhosis, and even hepatocellular carcinoma (HCC). About 2 billion people worldwide are infected with $\mathrm{HBV}$, of which 400 million are long-term carriers $[1,2]$. According to research reports by the World Health Organization (WHO), about 600,000 people die of HBV infection or liver diseases related to HBV infection every year [3,4]. China has the largest population of HBV-infected people worldwide and is confronting this large disease burden with efficient antiviral drugs.

At present, there are mainly two kinds of drugs used in the clinic, namely, interferons (INFs) with antiviral and immunoregulatory functions and nucleoside analogues that can inhibit the reverse transcription of HBV $[5,6]$. In recent years, although these drugs have a certain therapeutic effect on HBV infection in the clinic, there are serious side effects and drug resistance $[7,8]$. Thus, there are more and more researchers focus on natural product [9-11]. Some researches report a variety of natural medicines with novel structure and anti-HBV activity, including some candidate drugs with good anti-HBV effects. However, these reports were mainly involved in isolation and identification of compounds with anti-HBV activity; the mechanisms and targets of compounds were less. The mechanism of clinical medicines (nucleoside analogues and interferon) on anti-HBV is basically clear, but the emergence of drug-resistant HBV mutants weakens the clinical effects. Thus, the development of safe and effective anti-HBV drugs with novel mechanism is the top priority in the current research $[7,12]$. In this manuscript, in order to help researchers understand HBV and develop the anti-HBV drugs, all kinds of natural products (Table 1) with anti-HBV effects and the infection process of HBV (Figure 1) [13-17] were summarized. The types of natural products with anti-HBV activity include phenylpropanoids, flavonoids, alkaloids, terpenes, glycosides, and others (such as lactones and organic acids). 


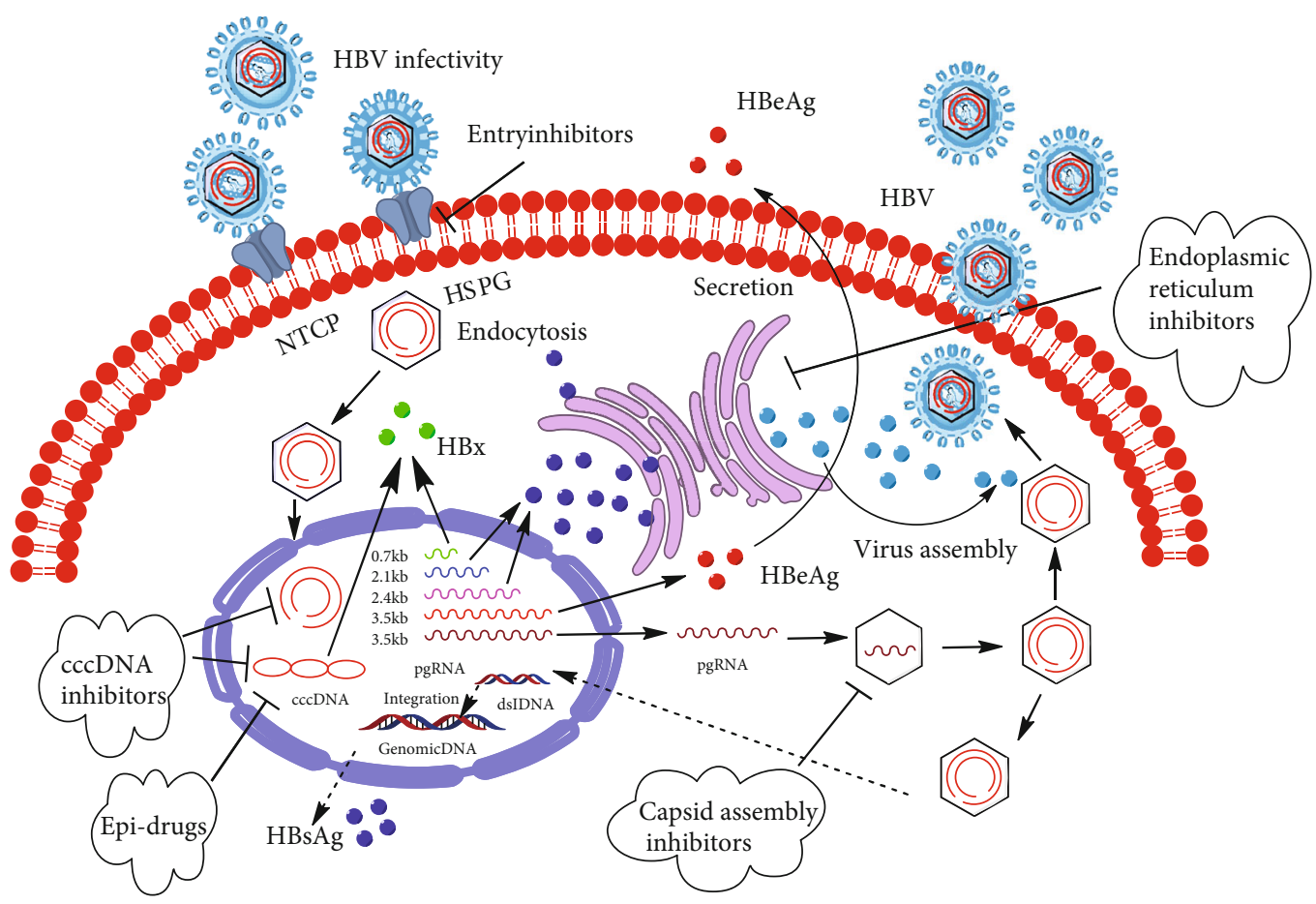

FIGURE 1: HBV life cycle and therapeutic targets. HBV life cycle: adsorption, penetration, biosynthesis, assembly, and secretion; therapeutic targets: entry inhibitors (NTCP and HSPG as the receptor-virus binding), cccDNA inhibitors (inhibiting the information of cccDNA), Epidrugs (inhibiting the viral RNA synthesis), endoplasmic reticulum inhibitors (inhibiting the viral capsid assembly), and glucosidese inhibitors (inhibiting the secretion of HBV proteins).

\section{The Natural Products of Anti-HBV}

2.1. Phenylpropanoids. Phenylpropanins have a wide range of biological activities, including antitumor, antivirus, liver protection, and antioxidation. For example, a variety of lignans in fruits of Schisandra chinensis have liver protective effects and can reduce serum alanine aminotransferase level. Schisandrae esteril A and its analogues have been used in the treatment of chronic hepatitis in China [18].

6-Hydroxyl-7-methoxyl-coumarin (1), isolated from the Streblus asper Lour core material, had significant anti-HBV effect on HepG 2.2.15 cells [19]. And the mechanism of compound $\mathbf{1}$ on anti-HBV effect may be related to its inhibition on secretion of hepatitis B virus surface antigen ( $\mathrm{HBsAg}$ ) and hepatitis $\mathrm{B}$ virus e antigen $(\mathrm{HBeAg})$, and the $\mathrm{IC}_{50}$ were $29.60 \mu \mathrm{M}$ (selective index, $\mathrm{SI}=6.76$ ) and $46.41 \mu \mathrm{M}$ $(\mathrm{SI}=4.31)$, respectively. Esculetin (2) from Microsorium fortunei (Moore) Ching. could not only inhibit the expression of the HBV antigens and HBV-DNA but also inhibit the expression of hepatitis $\mathrm{B}$ virus $\mathrm{X}(\mathrm{HBx})$ protein in a dose-dependent manner [20]. Chen et al. [21] isolated a series of phenylpropanins from the core material, bark and root of $S$. asper, all of which had significant anti-HBV activity. Among them, Magnatriol B (3) showed moderate antiHBV activity by inhibiting the secretion of HBsAg and HBeAg with low cytotoxicity. Honokiol (4) showed significant anti-HBV activity and strong inhibition on HBsAg and $\mathrm{HBeAg}$ with $\mathrm{IC}_{50}$ of $3.14 \mu \mathrm{M}(\mathrm{SI}=21.47)$ and $4.74 \mu \mathrm{M}$ $(\mathrm{SI}=14.22)$, respectively. The inhibition effect of honokiol on HBsAg and HBeAg was stronger than that of positive control, lamivudine. Isomagnolol (5) and isocarpine (6) from the bark and roots of $S$. asper showed significant anti-HBV activity by HepG 2.2.15 cell assay and significantly inhibited HBsAg secretion with $\mathrm{IC}_{50}$ of $10.34 \mu \mathrm{M}$ and $3.67 \mu \mathrm{M}$, respectively. For inhibiting the secretion of $\mathrm{HBeAg}, \mathrm{IC}_{50}$ was $8.83 \mu \mathrm{M}$ and $14.67 \mu \mathrm{M}$, respectively, without cytotoxicity. Honokiol (7) and $\left(7^{\prime} R, 8^{\prime} S, 7^{\prime} R, 8^{\prime} S\right)$-erythron-Strebluslignanol G (8), isolated from methanol extract of roots of $S$. asper, have strong anti-HBV activity by inhibiting the secretion of HBsAg and HBeAg. In addition, compounds 7 and 8 could significantly inhibit the replication of HBV-DNA, with $\mathrm{IC}_{50}$ of 9.02 and $8.67 \mu \mathrm{M}$, respectively $[22,23]$. Coumarin lignan (9) isolated from the stem of Kadsura heteroclita could inhibit the production of HBsAg and HBeAg with concentration of $25 \mu \mathrm{g} / \mathrm{mL}$. The inhibition of compound 9 (57\% and $48 \%)$ was even better than that of positive control, lamivudine (10\% and 46\%) [24]. Niranthin (10), isolated from Phyllanthus niruri, could inhibit the secretion of HBsAg and $\mathrm{HBeAg}$ in dose-dependent, with $\mathrm{IC}_{50}$ values of $16.5 \mu \mathrm{M}$ and $25.1 \mu \mathrm{M}$. The inhibition rates of $\mathbf{1 0}$ on $\mathrm{HBsAg}$ and $\mathrm{HBeAg}$ were $90.4 \%$ and $83.1 \%$ with $55.5 \mu \mathrm{M}$ while the inhibition rates of lamivudine were $55.6 \%$ and $44.5 \%$ with $43.6 \mu \mathrm{M}$. The anti-HBV effect of compound $\mathbf{1 0}$ was better than that of lamivudine. The inhibition rates of compound $\mathbf{1 0}$ on DHBV-DNA, HBsAg, and HBeAg were higher than that of lamivudine, and the recovery rate was smaller after drug withdrawal, indicating that compound $\mathbf{1 0}$ had a good prospect in the development of new anti-HBV drugs 
TABLE 1: The compounds with anti-HBV effects from natural products.

\begin{tabular}{|c|c|c|c|c|}
\hline No. & Compound & Target & Source & Ref \\
\hline 1 & 6-Hydroxyl-7-methoxyl-coumarin & $\mathrm{HBsAg}$ and $\mathrm{HBeAg}$ & S. asper & {$[19]$} \\
\hline 2 & Esculetin & $\begin{array}{l}\text { HBsAg, HBeAg, and } \\
\text { HBV-DNA }\end{array}$ & M. fortunei & {$[20]$} \\
\hline 3 & Magnatriol B & HBsAg and $\mathrm{HBeAg}$ & S. asper & {$[21]$} \\
\hline 4 & Honokiol & HBsAg and $\mathrm{HBeAg}$ & S. asper & {$[21]$} \\
\hline 5 & Isomagnolol & HBsAg & S. asper & {$[22,23]$} \\
\hline 6 & isocarpine & HBsAg & S. asper & {$[22,23]$} \\
\hline 7 & Honokiol & & S. asper & {$[22,23]$} \\
\hline 8 & $\begin{array}{l}\left(7^{\prime} R, 8^{\prime} S, 7^{\prime} R, 8^{\prime} S\right) \text {-erythron- } \\
\text { Strebluslignanol G }\end{array}$ & $\begin{array}{l}\text { HBsAg, HBeAg, and } \\
\text { HBV-DNA }\end{array}$ & S. asper & {$[22,23]$} \\
\hline 9 & Coumarin lignan & HBsAg and $\mathrm{HBeAg}$ & K. heteroclita & {$[24]$} \\
\hline 10 & Niranthin & HBsAg and $\mathrm{HBeAg}$ & P. niruri & {$[25]$} \\
\hline 11 & (+)-Dehydrod-iconiferyl alcohol & HBsAg & S. patens & {$[26]$} \\
\hline 12 & Dehydrozingerone & HBsAg & S. patens & {$[26]$} \\
\hline 13 & (+)-Cycloolivil- $4^{\prime}-O-\beta$-D-glucopyranoside & $\begin{array}{l}\text { HBsAg, HBeAg, and } \\
\text { HBV-DNA }\end{array}$ & S. chirayita & {$[27]$} \\
\hline 14 & Syringaresinol 4-O- $\beta$-D-glucopyranoside & HBsAg & S. chirayita & {$[27]$} \\
\hline 15 & Luteolin & HBsAg and $\mathrm{HBeAg}$ & S. macrosperma & {$[29]$} \\
\hline 16 & Isovitexin & $\begin{array}{l}\text { HBsAg, HBeAg, and } \\
\text { HBV-DNA }\end{array}$ & S. yunnanensis & {$[30]$} \\
\hline 17 & LPRP-Et-97543 & Core, $\mathrm{S}$, and preS promoters & L. muscari & {$[31]$} \\
\hline 18 & Quercetin & HBeAg & & {$[32]$} \\
\hline 19 & Glabaarachalcone & HBV-DNA & P. pinnata & {$[33]$} \\
\hline 20 & Isopongachromene & HBV-DNA & P. pinnata & {$[33]$} \\
\hline 21 & Isooriention & $\begin{array}{l}\text { HBsAg, HBeAg, and } \\
\text { HBV-DNA }\end{array}$ & S. mussotii & {$[34]$} \\
\hline 22 & Epimedium Hyde II & $\begin{array}{l}\text { HBsAg, HBeAg, and } \\
\text { HBV-DNA }\end{array}$ & & {$[35]$} \\
\hline 23 & Norbellidifolin & HBV-DNA & S. mussotii & {$[36]$} \\
\hline 24 & 1,5,8-Trihydroxy-3-methoxyxanthone & HBsAg and $\mathrm{HBeAg}$ & S. mussotii & {$[36]$} \\
\hline 25 & $\begin{array}{l}\text { 2-C- } \beta \text {-D-glucopyranosyl-1,3,7- } \\
\text { trihydroxyxanthone }\end{array}$ & HBsAg and $\mathrm{HBeAg}$ & S. mussotii & {$[36]$} \\
\hline 26 & Norswertianolin & HBV-DNA & S. mussotii & {$[36]$} \\
\hline 27 & Norswertianin-1-O- $\beta$-D-glucoside & HBV-DNA & S. mussotii & {$[36]$} \\
\hline 28 & 1,7-Dihydroxy-3,8-dimethoxyxanthone & HBV-DNA & S. mussotii & {$[36]$} \\
\hline 29 & $\begin{array}{l}\text { 7-O-[ } \beta \text {-D-xylopyranosyl- }(1 \rightarrow 2)-\beta \text {-D- } \\
\text { xylopyranosyl]-1,8-dihydroxy-3-methoxyxanthone }\end{array}$ & HBV-DNA & S. mussotii & {$[36]$} \\
\hline 30 & Mangiferin & HBV-DNA & S. mussotii & {$[36]$} \\
\hline 31 & $\begin{array}{l}\text { Methyl6,8-dihydroxy-3-methyl-9-oxo- } \\
\text { 9H-xanthene-1-carboxylate }\end{array}$ & HBsAg & Penicillium sp. & {$[37]$} \\
\hline 32 & 1,8-Dihydroxy-3,5-dimethoxyxanthone & $\begin{array}{l}\text { HBsAg, HBeAg, and } \\
\text { HBV-DNA }\end{array}$ & S. yunnanensis & {$[30]$} \\
\hline 33 & Norswertianolin & HBV-DNA & S. yunnanensis & {$[30]$} \\
\hline 34 & Neolancerin & $\begin{array}{l}\text { HBsAg, HBeAg, and } \\
\text { HBV-DNA }\end{array}$ & S. yunnanensis & {$[30]$} \\
\hline 35 & 1,5,8-Trihydroxy-3-methoxyxanthone & HBeAg and HBV-DNA & S. delavayi & {$[38]$} \\
\hline 36 & $(-)-2^{\prime} R$-1-hydroxyisorhodoptilometrin & HBsAg and HBeAg & Penicillium sp. & {$[37]$} \\
\hline 37 & Asterric acid & HBsAg & Penicillium sp. & {$[37]$} \\
\hline 38 & Questinol & HBsAg & Penicillium sp. & {$[37]$} \\
\hline 39 & Endocrocin & HBsAg & Penicillium sp. & {$[37]$} \\
\hline
\end{tabular}


TABle 1: Continued.

\begin{tabular}{|c|c|c|c|c|}
\hline No. & Compound & Target & Source & Ref \\
\hline 40 & $(+)-2^{\prime} S$-isorhodoptilometrin & HBsAg & Penicillium sp. & [37] \\
\hline 41 & Sulochrin & HBsAg & Penicillium sp. & [37] \\
\hline 42 & Monochlorsulochrin & HBsAg and $\mathrm{HBeAg}$ & Penicillium sp. & [37] \\
\hline 43 & Dihydrogeodin & HBsAg & Penicillium sp. & [37] \\
\hline 44 & $\begin{array}{l}\text { 1,3-Dihydroxy-2-hydroxymethyl-9, } \\
\text { 10-anthraquinone }\end{array}$ & $\mathrm{HBeAg}$ and $\mathrm{HBsAg}$ & P. connata & [40] \\
\hline 45 & Rubiadin & $\begin{array}{l}\mathrm{HBeAg}, \mathrm{HBsAg}, \mathrm{HBx} \\
\text { and HBV-DNA }\end{array}$ & P. connata & [40] \\
\hline 46 & Anthraquinone bile acid conjugates & HBeAg and HBsAg & P. connata & [40] \\
\hline 47 & Aloin B & HBV-DNA polymerase & Aloe vera & [41] \\
\hline 48 & Aloe-emodin & CYP3A4 & Aloe vera & [41] \\
\hline 49 & Hypericin & $\begin{array}{l}\text { HBsAg, HBeAg, HBV- } \\
\text { DNA, and pgRNA }\end{array}$ & & [42] \\
\hline 50 & Ursolic acid & HBsAg and HBeAg & S. asper & [19] \\
\hline 51 & $\mathrm{MH}$ & HBsAg and $\mathrm{HBeAg}$ & $V$. tenuifolia & [44] \\
\hline 52 & Sweriyunnangenin A & $\mathrm{HBsAg}$ and $\mathrm{HBeAg}$ & S. yunnanensis & [26] \\
\hline 53 & 3-Epitaraxerol & $\mathrm{HBsAg}$ and $\mathrm{HBeAg}$ & S. yunnanensis & [26] \\
\hline 54 & Oleanolic acid & HBsAg and HBeAg & S. yunnanensis & [26] \\
\hline 55 & Erythrocentaurin & $\begin{array}{l}\text { HBsAg, HBeAg, and } \\
\text { HBV-DNA }\end{array}$ & S. yunnanensis & [26] \\
\hline 56 & Astataricusones B & $\begin{array}{l}\text { HBeAg, HBV-DNA, } \\
\text { and HBsAg }\end{array}$ & A. tataricus & [45] \\
\hline 57 & Epishionol & $\mathrm{HBeAg}$ and $\mathrm{HBV}$-DNA & A. tataricus & [45] \\
\hline 58 & Astershionones C & $\begin{array}{l}\text { HBsAg, } \mathrm{HBeAg} \\
\text { and HBV-DNA }\end{array}$ & A. tataricus & [46] \\
\hline 59 & $4^{\prime \prime}$-Hydrox ${ }^{\prime \prime} y-3^{\prime \prime}$-methoxyalbiflorin & $\begin{array}{l}\mathrm{HBsAg}, \mathrm{HBeAg} \\
\text { and } \mathrm{HBV}-\mathrm{DNA}\end{array}$ & P. sinjiangensis & [47] \\
\hline 60 & $\begin{array}{c}6^{\prime}-O-p \text {-hydroxybenzoyl- } 4^{\prime \prime}- \\
\text { Hydroxyalbiflorin }\end{array}$ & $\begin{array}{l}\text { HBsAg, HBeAg, } \\
\text { and HBV-DNA }\end{array}$ & P. sinjiangensis & [47] \\
\hline 61 & Albiflorin & $\begin{array}{l}\text { HBsAg, HBeAg, } \\
\text { and HBV-DNA }\end{array}$ & P. sinjiangensis & [47] \\
\hline 62 & Oxypaeoniflorin & $\begin{array}{l}\mathrm{HBsAg}, \mathrm{HBeAg} \\
\text { and } \mathrm{HBV}-\mathrm{DNA}\end{array}$ & P. sinjiangensis & [47] \\
\hline 63 & Paeoniflorin & $\begin{array}{l}\text { HBsAg, HBeAg, } \\
\text { and HBV-DNA }\end{array}$ & P. sinjiangensis & [47] \\
\hline 64 & Paeonins B & $\begin{array}{l}\text { HBsAg, HBeAg, } \\
\text { and HBV-DNA }\end{array}$ & P. sinjiangensis & [47] \\
\hline 65 & Benzoylpaeoniflorin & $\begin{array}{l}\text { HBsAg, HBeAg, } \\
\text { and HBV-DNA }\end{array}$ & P. sinjiangensis & [47] \\
\hline 66 & Perovskatone A & HBsAg & P. atriplicifolia & [48] \\
\hline 67 & Demethylsalvicanol & HBsAg & P. atriplicifolia & [48] \\
\hline 68 & Chrysanolide B & HBsAg and $\mathrm{HBeAg}$ & D. indicum & [49] \\
\hline 69 & Chrysanolide C & HBsAg and $\mathrm{HBeAg}$ & D. indicum & [49] \\
\hline 70 & Chrysanolide A & HBsAg and $\mathrm{HBeAg}$ & D. indicum & [49] \\
\hline 71 & Pimelotide A & HBsAg & P. elongata foliage & [50] \\
\hline 72 & Wikstroelide W & HBV-DNA & W. chamaedaphne & [51] \\
\hline 73 & Genkwanine P & & W. chamaedaphne & [51] \\
\hline 74 & laurifolioside A & & W. chamaedaphne & [51] \\
\hline 75 & 2-Epi-laurifolioside A & HBV-DNA & W. chamaedaphne & [51] \\
\hline 76 & Laurifolioside B & HBV-DNA & W. chamaedaphne & [51] \\
\hline
\end{tabular}


TABle 1: Continued.

\begin{tabular}{|c|c|c|c|c|}
\hline No. & Compound & Target & Source & Ref \\
\hline 77 & 2-Epi-laurifolioside B & HBV-DNA & W. chamaedaphne & [51] \\
\hline 78 & Laurifolioside & HBV-DNA & W. chamaedaphne & [51] \\
\hline 79 & 2-epi-laurifolioside & HBV-DNA & W. chamaedaphne & [51] \\
\hline 80 & Oleanolic acid 3-O- $\beta$-D-glucuronopyranoside & HBV-DNA & A.philoxeroides & [52] \\
\hline 81 & 4,5-Dihydroblumenol & HBV-DNA & A.philoxeroides & [52] \\
\hline 82 & Swericinctosides A & HBV-DNA and HBsAg & S. cincta & [53] \\
\hline 83 & Swericinctoside B & HBV-DNA & S. cincta & [53] \\
\hline 84 & 9-Epi swertiamarin & HBV-DNA and HBsAg & S. cincta & [53] \\
\hline 85 & $2^{\prime}-O-m$-hydroxybenzoyl swertiamarin & HBV-DNA & S. cincta & {$[53]$} \\
\hline 86 & $4^{\prime \prime}$-O-actyl swertianoside E & HBV-DNA and HBsAg & S. cincta & {$[53]$} \\
\hline 87 & Swertiaside & HBV-DNA and HBsAg & S. cincta & [53] \\
\hline 88 & Swertianoside C & HBV-DNA and HBsAg & S. cincta & [53] \\
\hline 89 & Decentapicrin B & HBV-DNA & S. cincta & [53] \\
\hline 90 & ET derivatives $1 \mathrm{e}$ & HBV-DNA & Synthesis & [54] \\
\hline 91 & ET derivatives If & HBV-DNA & Synthesis & [54] \\
\hline 92 & Swertiakoside A & HBV-DNA & S. delavayi & [38] \\
\hline 93 & $2^{\prime}-O$-acetylswertiamarin & HBV-DNA & S. delavayi & {$[38]$} \\
\hline 94 & Asiaticoside & $\begin{array}{l}\text { HBsAg, HBeAg, } \\
\text { and HBV-DNA }\end{array}$ & H. sibthorpioides & {$[55]$} \\
\hline 95 & Diosgenin & HBsAg and $\mathrm{HBeAg}$ & & [56] \\
\hline 96 & 7-Eudesm-4(15)-ene-1 $\beta, 6 \alpha$-diol & HBV-DNA & A. capillaris & [57] \\
\hline 97 & Pumilaside A & $\begin{array}{l}\text { HBeAg, HBsAg, } \\
\text { and HBV-DNA }\end{array}$ & A. capillaris & [57] \\
\hline 98 & $\begin{array}{l}\text { Erythro-1-[1-oxo-9(3,4-methylenedioxyphenyl)- } \\
\text { 8,9-dihydroxy-2E-nonenyl]-piperidine }\end{array}$ & HBsAg and $\mathrm{HBeAg}$ & P. longum & [59] \\
\hline 99 & $\begin{array}{l}\text { Threo-1-[1-oxo-9(3,4-methylenedioxyphenyl)-8,9- } \\
\text { dihydroxy-2E-nonenyl]-piperidine }\end{array}$ & HBsAg and HBeAg & P. longum & [59] \\
\hline 100 & Piperine & HBsAg and HBeAg & P. longum & [59] \\
\hline 101 & Guineesine & HBsAg and HBeAg & P. longum & [59] \\
\hline 102 & $(2 E, 4 E)$-N-isobutyleicosa-2,4-dienamide & HBsAg and $\mathrm{HBeAg}$ & P. longum & {$[59]$} \\
\hline 103 & $\begin{array}{l}3 \beta, 4 \alpha \text {-dihydroxy-1-(3-phenylpropanoyl)- } \\
\text { piperidine-2-one }\end{array}$ & HBsAg and $\mathrm{HBeAg}$ & P. longum & {$[60]$} \\
\hline 104 & $\mathrm{DHCH}$ & $\begin{array}{l}\text { HBsAg, HBeAg, } \\
\text { cccDNA, and DNA }\end{array}$ & C. saxicola & {$[61]$} \\
\hline 105 & 8S-deca-9-en-4,6-diyne-1,8-diol & $\begin{array}{l}\text { HBsAg, HBeAg, } \\
\text { and HBV-DNA }\end{array}$ & A. capillaris & {$[63]$} \\
\hline 106 & $(S)$-deca-4,6,8-triyne-1,3-diol & $\begin{array}{l}\text { HBsAg, HBeAg, } \\
\text { and HBV-DNA }\end{array}$ & A. capillaris & {$[63]$} \\
\hline 107 & (S)-3-hydroxyundeca-5,7,9-triynoic acid & $\begin{array}{l}\text { HBsAg, HBeAg, } \\
\text { and HBV-DNA }\end{array}$ & A. capillaris & {$[63]$} \\
\hline 108 & $\begin{array}{l}\text { 3S-Hydroxyundeca-5,9-triynoic acid } \\
\text { 3-O- } \beta \text {-D-glucopyranoside }\end{array}$ & $\begin{array}{l}\text { HBsAg, HBeAg, } \\
\text { and HBV-DNA }\end{array}$ & A. capillaris & {$[63]$} \\
\hline 109 & Atractylodin & $\begin{array}{l}\text { HBsAg, HBeAg, } \\
\text { and HBV-DNA }\end{array}$ & A. capillaris & {$[63]$} \\
\hline 110 & Dendroarboreol B & $\begin{array}{l}\text { HBsAg, HBeAg, } \\
\text { and HBV-DNA }\end{array}$ & A. capillaris & {$[63]$} \\
\hline 111 & Dehydrofalcarinol & $\begin{array}{l}\text { HBsAg, HBeAg, } \\
\text { and HBV-DNA }\end{array}$ & A. capillaris & {$[63]$} \\
\hline 112 & Dehydrofalcarindiol & $\begin{array}{l}\text { HBsAg, HBeAg, } \\
\text { and HBV-DNA }\end{array}$ & A. capillaris & {$[63]$} \\
\hline
\end{tabular}


TABle 1: Continued.

\begin{tabular}{|c|c|c|c|c|}
\hline No. & Compound & Target & Source & Ref \\
\hline 113 & (E)-deca-2-en-4,10-diol & $\begin{array}{l}\text { HBsAg, HBeAg, } \\
\text { and HBV-DNA }\end{array}$ & A. capillaris & {$[63]$} \\
\hline 114 & (Z)-deca-2-en-4,10-diol & $\begin{array}{l}\text { HBsAg, HBeAg, } \\
\text { and HBV-DNA }\end{array}$ & A. capillaris & {$[63]$} \\
\hline 115 & 8-Diol 1-O- $\beta$-D-glucopyranoside & $\begin{array}{l}\text { HBsAg, HBeAg, } \\
\text { and HBV-DNA }\end{array}$ & A. capillaris & {$[63]$} \\
\hline 116 & $\begin{array}{l}\text { 3S,8S-dihydroxydec-9-ene-4,6-diyne1- } \\
\text { O- } \beta \text {-D-glucopyranoside }\end{array}$ & $\begin{array}{l}\text { HBsAg, HBeAg, } \\
\text { and HBV-DNA }\end{array}$ & A. capillaris & {$[63]$} \\
\hline 117 & 5-Benzylthiophencarboxylic acid & $\begin{array}{l}\text { HBsAg, HBeAg, } \\
\text { and HBV-DNA }\end{array}$ & A. capillaris & {$[63]$} \\
\hline 118 & 2-Methyl-6-phenyl-4H-pyran-4-one & $\begin{array}{l}\mathrm{HBsAg}, \mathrm{HBeAg} \\
\text { and HBV-DNA }\end{array}$ & A. capillaris & {$[63]$} \\
\hline 119 & $\begin{array}{l}\text { 3S,8S-dihydroxydec-9-en-4,6-yne 1-O- } \\
\left(6^{\prime} \text {-O-caffeoyl }\right)-\beta \text {-D-glucopyranoside }\end{array}$ & $\begin{array}{l}\text { HBsAg, HBeAg, } \\
\text { and HBV-DNA }\end{array}$ & A. capillaris & {$[64]$} \\
\hline 120 & $\begin{array}{l}\text { 3S,8S-dihydroxydec-9-en-4,6-yne1-O- } \\
\left(2^{\prime} \text {-O-caff-eoyl)- } \beta \text {-D-glucopyranoside }\right.\end{array}$ & $\begin{array}{l}\text { HBsAg, HBeAg, } \\
\text { and HBV-DNA }\end{array}$ & A. capillaris & {$[64]$} \\
\hline 121 & $m$-Hydroxybenzoic acid & $\begin{array}{l}\text { HBsAg, HBeAg, } \\
\text { and HBV-DNA }\end{array}$ & S. mussotii & {$[34]$} \\
\hline 122 & $p$-Hydroxybenzoic acid & $\begin{array}{l}\mathrm{HBsAg}, \mathrm{HBeAg} \\
\text { and } \mathrm{HBV}-\mathrm{DNA}\end{array}$ & S. mussotii & {$[34]$} \\
\hline 123 & $m$-Hydroxy benzenmethanol & $\begin{array}{l}\text { HBsAg, HBeAg, } \\
\text { and HBV-DNA }\end{array}$ & S. mussotii & {$[34]$} \\
\hline 124 & 3,4-Dihydroxybenzoic acid & $\begin{array}{l}\text { HBsAg, HBeAg, } \\
\text { and HBV-DNA }\end{array}$ & S. mussotii & {$[34]$} \\
\hline 125 & Ethyl 3,4-dihydroxybenzoate & $\begin{array}{l}\text { HBsAg, HBeAg, } \\
\text { and HBV-DNA }\end{array}$ & S. mussotii & {$[34]$} \\
\hline 126 & Ethyl 2,5-dihydroxybenzoate & $\begin{array}{l}\text { HBsAg, HBeAg, } \\
\text { and HBV-DNA }\end{array}$ & S. mussotii & {$[34]$} \\
\hline 127 & $3,3^{\prime}, 5$-Trihydroxybiphenyl & HBeAg & S. chirayita & {$[27]$} \\
\hline 128 & TaraffinisosideA & HBsAg and $\mathrm{HBeAg}$ & T. affinis & {$[65]$} \\
\hline 129 & Descaffeoyl crenatoside & HBsAg and $\mathrm{HBeAg}$ & T. affinis & {$[65]$} \\
\hline 130 & $\begin{array}{c}\text { 3,4-Dihydroxyphenylethanol-8-O- } \\
\text { [ } \beta \text {-D-apiofuranosyl }(1 \rightarrow 3)]-\beta \text {-D-glucopyranoside }\end{array}$ & $\mathrm{HBsAg}$ and $\mathrm{HBeAg}$ & T. affinis & {$[65]$} \\
\hline 131 & p-Hydroxy acetophenone (PHAP) & HBsAg & A. morrisonensis & {$[66]$} \\
\hline 132 & $p$-HAP derivative $2 \mathrm{f}$ & HBV-DNA & A. capillaris & {$[67]$} \\
\hline 133 & Matijin-Su & HBV-DNA & D. repens & {$[68]$} \\
\hline 134 & $\begin{array}{l}\mathrm{N} \text {-[N-(3,4-dimethoxy-benzoyl)-L-phenylalanyl }]- \\
\text { O-propionyl-L-phenylalaninol }\end{array}$ & HBV-DNA & Synthesis & {$[71]$} \\
\hline 135 & $\begin{array}{l}\mathrm{N} \text {-[N-(3,4-dimethoxy-benzoyl)-L-phenylalanyl]- } \\
\text { 4-ethoxy-L-phenylalaninol }\end{array}$ & HBV-DNA & Synthesis & {$[71]$} \\
\hline 136 & $\begin{array}{c}\mathrm{N} \text {-[N-(3,4-Dimethoxy-benzoyl)-L-phenylalanyl]- } \\
\text { 4-ethoxycarbonylmethyl-L-tyrosinol }\end{array}$ & HBV-DNA & Synthesis & {$[71]$} \\
\hline 137 & $\begin{array}{l}\mathrm{N} \text {-[N-(4-chlorobenzoyl)-O-methyl- } \\
\text { L-tyrosyl]-L-Phenylalaninol }\end{array}$ & HBV-DNA & Synthesis & {$[72]$} \\
\hline 138 & $\begin{array}{l}\text { N-[N-(4-chlorobenzoyl)-O-propyl- } \\
\text { L-tyrosyl]-L-Phenylalaninol }\end{array}$ & HBV-DNA & Synthesis & {$[72]$} \\
\hline 139 & $\begin{array}{l}\mathrm{N} \text {-[N-(4-chlorobenzoyl)-O-isopropyl- } \\
\text { L-tyrosyl]-L-Phenylalaninol }\end{array}$ & HBV-DNA & Synthesis & {$[72]$} \\
\hline 140 & $\begin{array}{l}\text { N-[N-(3-trifluoromethylbenzoyl)- } \\
\text { L-tyrosyl]-L-Phenylalaninol }\end{array}$ & HBV-DNA & Synthesis & {$[73]$} \\
\hline 141 & $\begin{array}{l}\mathrm{N} \text {-[N-(3-trifluoromethylbenzoyl)- } \\
\text { L-phenylalanyl]-O-propionyl- } \\
\text { L-tyrosine methyl ester }\end{array}$ & HBV-DNA & Synthesis & {$[73]$} \\
\hline
\end{tabular}


TABle 1: Continued.

\begin{tabular}{|c|c|c|c|c|}
\hline No. & Compound & Target & Source & Ref \\
\hline 142 & $\begin{array}{l}\mathrm{N} \text {-[N-(3-trifluoromethylbenzoyl)- } \\
\text { L-phenylalanyl]-O-ethyl-L-tyrosine }\end{array}$ & HBV-DNA & Synthesis & [73] \\
\hline 143 & Compound $8 \mathrm{n}$ & HBV-DNA & Synthesis & [74] \\
\hline 144 & Compound 80 & HBV-DNA & Synthesis & [74] \\
\hline 145 & Compound $9 \mathrm{a}$ & HBV-DNA & Synthesis & [75] \\
\hline 146 & Compound $9 \mathrm{~b}$ & HBV-DNA & Synthesis & [75] \\
\hline 147 & Compound $9 \mathrm{c}$ & HBV-DNA & Synthesis & {$[75]$} \\
\hline 148 & Cyclic (glycine-L-proline) & $\begin{array}{l}\text { HBsAg, HBeAg, } \\
\text { and HBV-DNA }\end{array}$ & & [76] \\
\hline 149 & Cyclic (4-hydroxy proline-phenylalanine) & $\begin{array}{l}\mathrm{HBsAg}, \mathrm{HBeAg} \\
\text { and } \mathrm{HBV}-\mathrm{DNA}\end{array}$ & & {$[76]$} \\
\hline 150 & Cyclic (L-2-hydroxy proline-phenylalanine) & $\begin{array}{l}\text { HBsAg, HBeAg, } \\
\text { and HBV-DNA }\end{array}$ & & [76] \\
\hline 151 & $\mathrm{~N}$-acetyl phenylalanine & HBsAg and $\mathrm{HBeAg}$ & P. crinitum & [77] \\
\hline 152 & Two dimers of oxanthrone & $\begin{array}{l}\text { HBsAg, HBeAg, } \\
\text { and HBV-DNA }\end{array}$ & S. punicea & [78] \\
\hline 153 & Iridoid lactone & $\begin{array}{l}\text { HBsAg, HBeAg, } \\
\text { and HBV-DNA }\end{array}$ & S. punicea & {$[78]$} \\
\hline 154 & Anislactone B & HBeAg & I. henryi & [79] \\
\hline 155 & NC-8 & HBsAg and HBeAg & Synthesis & [80] \\
\hline 156 & IN-4 & HBV-DNA & Synthesis & [81] \\
\hline 157 & Scoparamide A & $\begin{array}{l}\text { HBsAg, HBeAg, } \\
\text { and HBV-DNA }\end{array}$ & A. scoparia & [64] \\
\hline 158 & Cichoric acid & DHBV-DNA & C. intybus & [82] \\
\hline 159 & Rosmarinic acid & $\varepsilon$-Pol binding & & [83] \\
\hline 160 & 3-Caffeoylquinicacid & $\begin{array}{l}\text { HBsAg, HBeAg, } \\
\text { and HBV-DNA }\end{array}$ & L. japonica & [84] \\
\hline 161 & Cryptochlorogenic acid & HBV-DNA & L. japonica & [84] \\
\hline 162 & Neochlorogenic acid & HBV-DNA & L. japonica & [84] \\
\hline 163 & 3,5-Dicaffeoylquinic acid & $\begin{array}{l}\text { HBsAg, HBeAg, } \\
\text { and HBV-DNA }\end{array}$ & L. japonica & {$[84]$} \\
\hline 164 & 4,5-Dicaffeoylquinic acid & $\begin{array}{l}\text { HBsAg, HBeAg, } \\
\text { and HBV-DNA }\end{array}$ & L. japonica & {$[84]$} \\
\hline 165 & 3,4-Dicaffeoylquinic acid & $\begin{array}{l}\mathrm{HBsAg}, \mathrm{HBeAg} \\
\text { and } \mathrm{HBV}-\mathrm{DNA}\end{array}$ & L. japonica & [84] \\
\hline
\end{tabular}

in vivo [25]. (+)-Dehydrod-iconiferyl alcohol (11) and dehydrozingerone (12) showed moderate inhibitory activities on the secretion of HBsAg with $\mathrm{IC}_{50}$ value of $1.94 \mathrm{mM}$ (SI 1.06) and $0.50 \mathrm{mM}$ (SI 2.88) [26]. (+)-Cycloolivil- $4^{\prime}-O-$ $\beta$-D-glucopyranoside (13) and syringaresinol $4^{\prime \prime}-O-\beta$-Dglucopyranoside (14) showed inhibitory activity on HBsAg secretion with $\mathrm{IC}_{50}$ values of $0.31 \pm 0.045$ and $1.49 \pm$ $0.033 \mathrm{mM}$. In particular, compound 13 exhibited inhibition not only on the secretions of HBsAg and HBeAg with $\mathrm{IC}_{50}$ values of $0.31 \pm 0.045 \mathrm{mM} \quad(\mathrm{SI}=4.29)$ and $0.77 \pm$ $0.076 \mathrm{mM} \quad(\mathrm{SI}=1.75)$, respectively, but also on $\mathrm{HBV}$ DNA replication with an $\mathrm{IC}_{50}$ value of $0.29 \pm 0.034 \mathrm{mM}$ $(\mathrm{SI}=4.66)$ [27]. The chemical structures of compounds 1 14 showed in Figure 2.

2.2. Flavonoids. Flavonoids have a wide range of biological activities, including anti-inflammatory, anticancer, and anti- bacterial. It has a prominent role in protecting liver; for example, silymarin shows significant effect on protecting liver and has successfully developed into a protect liver medicine [28].

Recently, flavonoids have been reported with good antiHBV effect. Luteolin (15), isolated from Swertia macrosperma C. B. Clark, could significantly inhibit the secretion of $\mathrm{HBsAg}$ and $\mathrm{HBeAg}$ with $\mathrm{IC}_{50}$ values of $0.02 \mathrm{mM}$ on $\mathrm{HepG}$ 2.2.15 cells in vitro [29]. Isovitexin (16) isolated from $S$. yunnanensis had good anti-HBV effect, which could not only inhibit the secretion of $\mathrm{HBsAg}$ and $\mathrm{HBeAg}$, with $\mathrm{IC}_{50}$ values of $0.04 \mathrm{mM},<0.03 \mathrm{mM}$, and $0.23 \mathrm{mM}$, but also significantly inhibit the replication of $\mathrm{HBV}-\mathrm{DNA}$, with the $\mathrm{IC}_{50}$ values of $0.09 \mathrm{mM},<0.01 \mathrm{mM}$, and $0.05 \mathrm{mM}$ [30]. Huang et al. [31] isolated LPRP-Et-97543 (17) from Liriopemuscari (Decne.) L.H.Bailey, which had significant anti-HBV activity and could significantly reduce the activity of Core, $S$, and 
<smiles>COc1cc2oc(=O)ccc2cc1O</smiles>

1<smiles>C=CCc1ccc(O)c(-c2ccc(O)c(CC=C)c2)c1</smiles>

4<smiles>COc1cc(C2c3cc(O)c(OC)cc3C[C@H](CO)[C@H]2CO)ccc1O</smiles>

7<smiles>COC[C@@H](Cc1ccc2c(c1OC)OCO2)[C@H](COC)Cc1ccc(OC)c(OC)c1</smiles>

10<smiles>COc1cc2c(cc1O)[C@@H](c1ccc(O[C@@H]3O[C@H](CO)[C@@H](O)[C@H](O)[C@H]3O)c(OC)c1)[C@H](CO)[C@@](O)(CO)C2</smiles>

13<smiles>O=C1CCc2cc(O)c(O)cc2O1</smiles>

2<smiles>C=CCc1ccc(Oc2cc(CC=C)ccc2C)cc1</smiles>

5

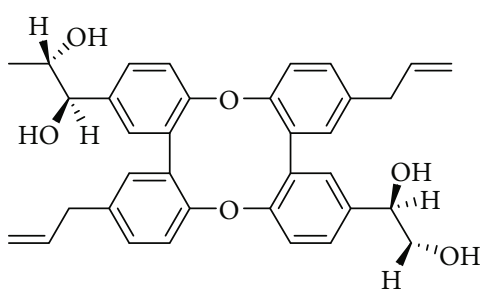

8<smiles>COc1ccccc1O</smiles>

11<smiles>C=CCc1cc(-c2cc(O)ccc2O)ccc1O</smiles><smiles>C=CCc1ccc(O)c(-c2cc(CC=C)ccc2O)c1</smiles><smiles>O=c1oc2cc3c(cc2cc1[C@@H](CO)Cc1ccc2c(c1)OCO2)OCO3</smiles><smiles>COc1cc(/C=C/C(C)=O)ccc1O</smiles>

12

FIGURE 2: Chemical structures of representative anti-HBV phenylpropanoids 1-14.

preS promoters. Moreover, the mechanism may be that it inhibited the replication of viral DNA by regulating viral proteins. In recent years, molecular docking technology was used to screen the active ingredients against $\mathrm{HBV}$, a 3D structure of HBV polymerase (Pol/RT) was modeled and docked with the active compounds, and quercetin (18) was proved that could enhance its anti-HBV activity up to $10 \%$ [32]. In addition, some researchers found that glabaarachalcone (19) and isopongachromene (20), isolated from $P$. pinnata, could bound with HBV-DNA polymerase protein target [33]. Isooriention (21), isolated from S. mussotii, displayed significant anti-HBV activities against the secretions of HBsAg and
$\mathrm{HBeAg}$ with $\mathrm{IC}_{50}$ value of 0.79 and $1.12 \mathrm{mM}$, as well as $\mathrm{HBV}$-DNA replication with $\mathrm{IC}_{50}$ value of $0.02 \mathrm{mM}$ [34]. Epimedium Hyde II (22), a potential Chinese herbal active ingredient against $\mathrm{HBV}$, could inhibit the replication of HBV-DNA and the expression of HBsAg and HBeAg in the serum of HBV-replicated C57BL/6 mice [35]. The chemical structures of compounds 15 22 showed in Figure 3.

2.3. Xanthones. Norbellidifolin (23), 1,5,8-trihydroxy-3methoxyxanthone (24), 2-C- $\beta$-D-glucopyranosyl-1,3,7-trihydroxyxanthone (25), norswertianolin (26), norswertianin-1-O- $\beta$-D-glucoside (27), 1,7-dihydroxy-3,8- 
<smiles>O=c1cc(-c2ccc(O)c(O)c2)oc2cc(O)cc(O)c12</smiles>

15<smiles>C[C@@H]1O[C@H](Oc2c(-c3ccc(O)c(O)c3)oc3cc(O)cc(O)c3c2=O)[C@H](O)[C@@H](O)[C@@H]1O</smiles><smiles>O=c1cc(-c2cccc(O)c2)oc2cc(O)c(C(F)(F)Cl)c(O)c12</smiles>

21<smiles>O=c1cc(-c2ccc(O)c(O)c2)oc2cc(O)c(Cl)c(O)c12</smiles><smiles>O=C1c2c(cc(O)c(Cl)c2O)OC[C@@H]1Cc1ccc(O)cc1</smiles>

17<smiles>COc1cc2c(=O)cc(-c3ccc4c(c3)OCO4)oc2c2c1OC(C)(C)C=C2</smiles>

20

FIgURE 3: Chemical structures of representative anti-HBV flavonoids 15-22.

dimethoxyxanthone (28), 7-O-[ $\beta$-D-xylopyranosyl-( $1 \rightarrow 2)$ $\beta$-D-xylopyranosyl]-1,8-dihydroxy-3-methoxyxanthone (29), and mangiferin (30) showed remarkable inhibition on HBV-DNA replication with $\mathrm{IC}_{50}$ values from $0.01 \mathrm{mM}$ to $0.13 \mathrm{mM}$. Compounds 23-25 with three or more hydroxy groups showed significant inhibitory activity with $\mathrm{IC}_{50}$ values of $0.77,>0.98$, and $0.21 \mathrm{mM}$ for HBsAg, and $<0.62,0.35$, and $0.04 \mathrm{mM}$ for $\mathrm{HBeAg}$, respectively. It was deduced that hydroxy groups in the xanthone structure were essential for maintaining the inhibitory effects on the secretion of HBsAg and HBeAg. Glycosidation of hydroxy groups led to activity decreasing against $\mathrm{HBsAg}$ and $\mathrm{HBeAg}$ by comparing the activity of compounds $\mathbf{2 4}, \mathbf{2 6}$, and $\mathbf{2 7}$. It was concluded that two or more hydroxy groups were essential for inhibiting HBV-DNA replication, and methylation of hydroxy groups decreased or abolished anti-HBV activity. In addition, the position of the hydroxy groups of the isolated xanthones did not significantly affect the inhibition on HBV-DNA replication. The preliminary structure-activity relationships were deduced as (1) the anti-HBV activity of xanthones depends on the structure and substitution pattern of the hydroxy groups; (2) the hydroxy groups play very important roles in the anti-HBV activity; (3) the anti-HBV activity will be decreased after methylation orglycosidation [36]. Methyl6,8-dihydroxy-3-methyl-9-oxo-9H-xanthene-1-carboxylate (31), isolated from mangrove-derived aciduric fungus Penicillium sp., inhibited HBsAg secretion more effectively than that of the positive control, 3TC, in a dosedependent manner [37]. 1,8-Dihydroxy-3,5-dimethoxyx- anthone (32), norswertianolin (33), and neolancerin (34), isolated from S. yunnanensis, had good anti-HBV effect. Among of them, compound $\mathbf{3 4}$ could not only inhibit the secretion of $\mathrm{HBsAg}$ and $\mathrm{HBeAg}$, with $\mathrm{IC}_{50}$ values of 0.21 , 0.10 , and 1.51 , but also significantly inhibit the replication of HBV-DNA, with the $\mathrm{IC}_{50}$ values of $0.09 \mathrm{mM},<0.01 \mathrm{mM}$, and $0.05 \mathrm{mM}$. However, compounds $\mathbf{3 2}$ and $\mathbf{3 3}$ only showed inhibitory effect on HBV-DNA replication, which may be caused by methylation or glycoylation of the hydroxyl group of the compounds [30]. 1,5,8-Trihydroxy-3-methoxyxanthone (35) exhibited significant inhibitory activity on HBV-DNA replication with $\mathrm{IC}_{50}$ values of 0.09 and 0 . $05 \mathrm{~m} \mathrm{~mol} \cdot \mathrm{L}^{-1}$ (SI of 10.89 ) and showed potent activity against the secretion of $\mathrm{HBeAg}$ with $\mathrm{IC}_{50}$ values of 0.35 (SI of $\geq 2.80$ ) [38]. The chemical structures of compounds 23 35 are shown in Figure 4.

2.4. Anthroquinones. Anthroquinones, often found in the metabolites of lichens and fungi of higher plants and lower plants, have the functions of hemostasis, antisepsis, purgation, and diuretic. In recent years, the anti-HBV activity of anthroquinones was reported [39].

$(-)-2^{\prime} \quad R$-1-hydroxyisorhodoptilometrin (36), asterric acid (37), questinol (38), endo crocin (39), (+)-2' S-isorhodoptilometrin (40), sulochrin (41), monochlorsulochrin (42), and dihydrogeodin (43) were isolated from mangrovederived aciduric fungus Penicillium sp. and inhibited HBsAg secretion more effectively than that of the positive control, $3 \mathrm{TC}$, in a dose-dependent manner. Compared with $13 \%$ 
<smiles>[R]c1c([R])c([R])c2c(=O)c3c([R])c([R])c([R])c([R])c3oc2c1[R]</smiles>

$\begin{array}{clcccccc}\text { R1 } & \text { R2 } & \text { R3 } & \text { R4 } & \text { R5 } & \text { R6 } & \text { R7 } & \text { R8 } \\ \text { OH } & \text { H } & \text { OH } & \text { H } & \text { OH } & \text { H } & \text { H } & \text { OH } \\ \text { OH } & \text { H } & \text { OMe } & \text { H } & \text { OH } & \text { H } & \text { H } & \text { OH } \\ \text { OH } & \text { Glc } & \text { OH } & \text { H } & \text { H } & \text { H } & \text { OH } & \text { H } \\ \text { OGlc } & \text { H } & \text { OH } & \text { H } & \text { OH } & \text { H } & \text { H } & \text { OH } \\ \text { OGlc } & \text { H } & \text { OH } & \text { H } & \text { H } & \text { H } & \text { OH } & \text { OH } \\ \text { OH } & \text { H } & \text { OMe } & \text { H } & \text { H } & \text { H } & \text { OH } & \text { OMe } \\ \text { OH } & \text { H } & \text { OMe } & \text { H } & \text { H } & \text { H } & \text { OXyl-Xyl } & \text { OH } \\ \text { OH } & \text { Glc } & \text { OH } & \text { H } & \text { H } & \text { OH } & \text { OH } & \text { H }\end{array}$<smiles>O=c1c2c(O)cc(O)cc2oc2c(O)ccc(O)c12</smiles>

33<smiles>O=c1c2c(Cl)c(Cl)c(O)cc2oc2c(O)cc(O)c(O)c12</smiles>

34<smiles>COC(=O)c1cc(C)cc2oc3cc(O)cc(O)c3c(=O)c12</smiles>

31<smiles>COc1cc(O)c2c(=O)c3c(O)c(OC)cc(OC)c3oc2c1</smiles>

32<smiles>COc1cc(O)c2c(=O)c3c(O)ccc(O)c3oc2c1</smiles>

35

FIGURE 4: Chemical structures of representative anti-HBV xanthones 23-35.

inhibition by 3TC, compounds 36 and 42 at $20 \mu \mathrm{M}$ inhibited $\mathrm{HBeAg}$ secretion by 17 and 35\%, respectively. Compound 36 showed much stronger antihepatitis B virus activity than that of the positive control, lamivudine, strongly inhibiting the secretion on HBsAg and HBeAg of HepG 2.2.15 cells. These results showed that extremophiles are a valuable resource of bioactive compounds, and that $\mathrm{pH}$ regulation is an effective strategy to induce metabolite production in aciduric fungi [37]. Peng et al. [40] found that 1,3-dihydroxy-2-hydroxymethyl-9,10-anthraquinone (44), Rubiadin (45), and Anthraquinone bile acid conjugates (46) have significant anti-HBV effects on HepG2.2.15 cells. The $\mathrm{IC}_{50}$ values of them were $12.41,8.03,17.05$, and $8.13 \mathrm{~g} / \mathrm{mL}$, respectively. When the drug concentrations were $8 \mathrm{~g} / \mathrm{mL}$, the inhibitory rates of $\mathrm{HBeAg}$ were $61.42 \%, 43.79 \%$, and $69.30 \%$, respectively. The inhibitory rates of HBsAg secreted by cells were $6.15 \%, 23.34 \%$, and $43.38 \%$, respectively. Particularly, compound 45 could not only significantly decrease HBeAg and HBsAg secretion level and inhibit HBV-DNA replication but also inhibit the proliferation of the cells and HBx protein expression in a dose-dependent manner, which might become a novel anti-HBV drug candidate. Mohammad $\mathrm{K}$ et al. [41] reported that anti-HBV potential of AV-derived anthroquinones, possibly via HBV-DNA polymerase inhibition for the first time. Although aloin B (47) exhibited novel antiviral effect, aloe-emodin (48) appeared as the most promising anti-HBV natural drug with CYP3A4 activating property towards its enhanced therapeutic efficacy. Lan et al. [42] found that hypericin (49) could significantly reduce the expression of $\mathrm{HBV}-\mathrm{DNA}$ and the expression level of HBsAg and HBeAg, which was similar to lamivu- dine, 3TC. The chemical structures of compounds 36 49 are shown in Figure 5.

2.5. Terpenoids. Terpenes are a kind of compounds with isoprene as the basic structural unit. Terpenes have extensive biological activities, mainly including anti-inflammatory and antiviral effects [43].

Li et al. [19] isolated ursolic acid (50) from S. asper core material. Compound $\mathbf{5 0}$ had strong anti-HBV activity by inhibiting the production of $\mathrm{HBsAg}$ and $\mathrm{HBeAg}$, with $\mathrm{IC}_{50}$ of 89.91 and $97.61 \mu \mathrm{M}$. A triterpenoid, named $\mathrm{MH}$ (51), was isolated from the Vicia tenuifolia Roth, which had significant inhibitory effect on the secretion of HBsAg and $\mathrm{HBeAg}$ in a dose-dependent manner [44]. Sweriyunnangenin A (52), 3-epitaraxerol (53), oleanolic acid (54), and erythrocentaurin (55), isolated from $S$. yunnanensis, could inhibit the secretion of HBsAg with $\mathrm{IC}_{50}$ values of $0.28,0.70$, and $1.26 \mathrm{mM}$, respectively. They also had good inhibitory effects on the secretion of $\mathrm{HBeAg}$, with the $\mathrm{IC}_{50}$ values of $0.29,1.41$, and $0.94 \mathrm{mM}$, respectively. Especially, compound 55 could effectively inhibit the secretion of HBsAg and HBeAg, as well as the replication of $\mathrm{HBV}-\mathrm{DNA}$, due to its aldehyde group [26]. Zhou et al. [45] isolated a series of heptane terpenoids from the roots and rhizomes of Aster tataricus L. f. Among them, astataricusones $\mathrm{B}$ andepishionol (56-57) could inhibit the secretion of $\mathrm{HBeAg}$, with $\mathrm{IC}_{50}$ value of 18.6 and $40.5 \mu \mathrm{M}$, and the replication HBV-DNA, with $\mathrm{IC}_{50}$ value of 2.7 and $30.7 \mu \mathrm{M}$. In addition, compound $\mathbf{5 6}$ had inhibitory effect on the secretion of $\mathrm{HBsAg}$ with $\mathrm{IC}_{50}$ value of $23.5 \mu \mathrm{M}$. Zhou et al. [46] carried out further research on $A$. tataricus, and 6 new shionane-type triterpenes were isolated. 
<smiles>C[C@@H](O)Cc1cc(O)c2c(c1)C(=O)c1c(O)c(O)cc(O)c1C2=O</smiles><smiles>COC(=O)c1cc(O)cc(OC)c1Oc1cc(C)cc(O)c1C(=O)O</smiles><smiles>COc1cc(O)cc2c1C(=O)c1c(O)cc(CO)cc1C2=O</smiles><smiles>Cc1cc2c(c(O)c1C(=O)O)C(=O)c1c(O)cc(O)cc1C2=O</smiles><smiles>C[C@H](O)Cc1cc(O)c2c(c1)C(=O)c1cc(O)cc(O)c1C2=O</smiles><smiles>[R]C1=C(O)C(C(=O)c2c(OO)cc(O)cc2C(=O)OC)C(O)C([R])=C1C</smiles>

39<smiles>O=C1c2ccccc2C(=O)C2C(O)=C(CO)C(O)=CC12</smiles>

44<smiles>CC1=C(O)C2C(=O)c3ccccc3C(=O)C2C=C1O</smiles>
$42 \mathrm{R} 1=\mathrm{Cl}, \mathrm{R} 2=\mathrm{H}$ $43 \mathrm{R} 1=\mathrm{Cl}, \mathrm{R} 2=\mathrm{Cl}$

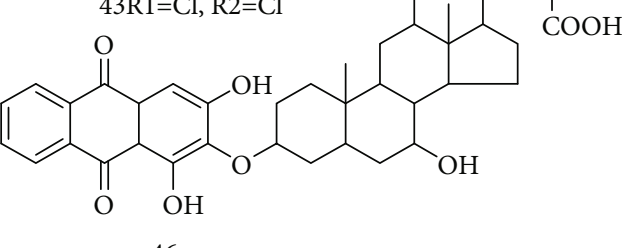<smiles>O=C1c2c(O)cccc2[C@H](C2O[C@H](CO)[C@@H](O)[C@H](O)[C@H]2O)c2cc(CO)cc(O)c21</smiles>

47<smiles>O=C1c2cccc(O)c2C(=O)c2c(O)cc(CO)cc21</smiles>

48<smiles></smiles>

49

FIGURE 5: Chemical structures of representative anti-HBV anthroquinones 36-49.

Among them, astershionones C (58) had good anti-HBV activity by inhibiting the secretion of HBsAg and HBeAg and the replication of $\mathrm{HBV}$-DNA with $\mathrm{IC}_{50}$ values of 23.0, 23.1, and $22.4 \mu \mathrm{M}$, respectively. Bi et al. [47] found that 7 monoterpenes ( $4^{\prime \prime}$-hydroxy- $3^{\prime \prime}$-methoxyalbiflorin (59), $6^{\prime}$ -O-p-hydroxybenzoyl-4" -Hydroxyalbiflorin (60), albiflorin (61), oxypaeoniflorin (62), paeoniflorin (63), paeonins B (64), and benzoylpaeoniflorin (65)) of the Paeonia sinjiangensis K. Y. Pan had anti-HBV activity and could inhibit the secretion of HBsAg and $\mathrm{HBeAg}$ as well as the replication of HBV-DNA. Among them, compound 59 had the highest anti-HBV activity, which was even better than that of positive drug, 3TC. Perovskatone A and demethylsalvicanol (66-67), isolated from Perovskia atriplicifolia, had anti-HBV activity. It was for the first report on the anti-HBV effect of $P$. atriplicifolia [48]. Chrysanolide B-C and A (68-70) were isolated from Dendranthema indicum, and compound $\mathbf{7 0}$ had unknown trimer carbon skeleton. Compounds 68-70 had good anti-HBV activity on HepG 2.2 .15 cell, and their antiHBV activity was positively correlated with the degree of polymerization [49]. In the anti-HBV test, Pimelotides A (71) showed significant inhibition on the secretion of $\mathrm{HBsAg}$, with an $\mathrm{IC}_{50}$ value of $0.016 \mathrm{~g} / \mathrm{mL}$ and TI up to 355.63 . However, the anti-HBV mechanism of compound 71 should be carried out for the further study [50]. Genkwanine P (73) and laurifolioside A (74), isolated from Wikstroemia chamaedaphne Meisn, exhibited potential antihepatitis B virus activities with $\mathrm{IC}_{50}$ values of 46.5 and $88.3 \mathrm{mg} / \mathrm{mL}$, respectively. Wikstroelide W (72), 2-epi-laurifolioside A (75), laurifolioside B (76), 2-epi-laurifolioside B (77),laurifolioside (78), and 2-epi-laurifolioside (79) showed certain inhibitory effects on HBV-DNA replication with the inhibition ratios ranging from $2.0 \%$ to $33.0 \%$ at the concentrations ranging from 0.39 to $6.25 \mathrm{mg} / \mathrm{mL}$ [51]. It is reported that the extracts of Alternantheraphiloxeroides (Mart.) Griseb have antiviral properties in vitro. And oleanolic acid 3-O- $\beta$-D-glucuronopyranoside (80) and 4,5-dihydroblumenol (81), isolated from the extracts, showed significant inhibition against HepG2.2.15 cells transected with cloned HBV-DNA; their inhibitive ratios were $85.38 \%$ and $87.37 \%$ at $50 \mu \mathrm{g} / \mathrm{mL}$, respectively [52]. Nine compounds $\mathbf{8 2 - 8 9}$ isolated from $S$. cincta, namely, swericinctosides A (82), swericinctoside B (83), 9-epi swertiamarin (84), $2^{\prime}$-O-m-hydroxybenzoyl swertiamarin (85), $4^{\prime \prime}$-O-actyl swertianoside E (86), swertiaside (87), swertianoside C (88), and decentapicrin B (89), possessed inhibitory activity on HBV-DNA replication with $\mathrm{IC}_{50}$ values from 0.05 to $1.83 \mathrm{mM}$. Compounds 82, 84, and 86-88 showed moderate activity against $\mathrm{HBsAg}$ with $\mathrm{IC}_{50}$ values in the range of $0.24-2.46 \mathrm{mM}$, and compounds 82, $\mathbf{8 4}, \mathbf{8 7}$, and 88 could inhibit HBV-DNA replication with 
$\mathrm{IC}_{50}$ values of $0.30-0.62 \mathrm{mM}$. Compound 87 exhibited the most promising activity against $\mathrm{HBV}$-DNA replication with an $\mathrm{IC}_{50}$ value of $0.05 \mathrm{mM}(\mathrm{SI}=29.1)$, as well as moderate activity against the HBsAg secretion $\left(\mathrm{IC}_{50}=0.79 \mathrm{mM}\right)$ [53]. Geng et al. [54] found that the anti-HBV activity of erythrocentaurin (ET) derivatives was significantly improved. In particular, ET derivatives 1e and If $(\mathbf{9 0}, \mathbf{9 1})$ showed the highest activity of inhibiting the replication of $\mathrm{HBV}$ DNA, with $\mathrm{IC}_{50}$ values of $0.026 \mathrm{mM}(\mathrm{SI}>70.8)$ and $0.045 \mathrm{mM}$ (SI > 36.0), respectively. Swertiakoside A (92) and $2^{\prime}$-O-acetylswertiamarin (93) exhibited significant inhibitory activity on $\mathrm{HBV}$-DNA replication with $\mathrm{IC}_{50}$ values from 0.05 to $1.46 \mathrm{mmol} \cdot \mathrm{L}^{-1}$ [38]. Huang et al. [55] isolated Asiaticoside (94) from Hydrocotyle sibthorpioides Lam and found that Asiaticoside could effectively inhibit the secretion of HBsAg and HBeAg. In addition, Asiaticoside could significantly reduce the transcription and replication of HBV-DNA by inhibiting the core, s1, s2, and $\mathrm{x}$ gene promoter activity. Liu et al. [56] found diosgenin (95) could effectively inhibit the secretion of HBsAg and HBeAg, with the inhibition rate reaching $40 \%$ and $50 \%$. 7-Eudesm-4(15)-ene-1 $\beta, 6 \alpha$-diol (96) and Pumilaside A (97), isolated from Artemisia capillaris, exhibited promising activity against $\mathrm{HBV}$-DNA replication with $\mathrm{IC}_{50}$ values of 19.70 and $12.01 \mu \mathrm{M}$, with high SI values of 105.5 and 139.2. In addition, compound $\mathbf{9 7}$ could also suppress the secretions of $\mathrm{HBsAg}$ and $\mathrm{HBeAg}$ with the $\mathrm{IC}_{50}$ values of $15.02 \mu \mathrm{M}(\mathrm{SI}=111.3)$ and $9.00 \mu \mathrm{M}(\mathrm{SI}=185.9)$ [57]. The chemical structures of compounds 50 97 showed in Figure 6.

2.6. Alkaloids. Alkaloids, a kind of natural nitrogen heterocyclic, have complex ring structure, most of which have physiological activity [58].

Jiang et al. [59] found that the ethanol extract of Piper longum L. fruit had good anti-HBV effect, and erythro-1-[1-oxo-9(3,4-methylenedioxyphenyl)-8,9-dihydroxy2E-nonenyl]-piperidine (98), threo-1-[1-oxo-9(3,4-methylenedioxyphenyl)-8,9-dihydroxy-2E-nonenyl]-piperidine (99), piperine (100), guineesine (101), and $(2 E, 4 E)-\mathrm{N}$-isobutyleicosa-2,4-dienamide (102) had significant inhibitory effect on the secretion of HBsAg and HBeAg on HepG 2.2.15 cells. $3 \beta, 4 \alpha$-dihydroxy-1-(3-phenylpropanoyl)-piperidine-2-one (103), isolated from $P$. longum ethanol extract, had significant anti-HBV activity and could inhibit the secretion of $\mathrm{HBsAg}$ and $\mathrm{HBeAg}$, with $\mathrm{IC}_{50}$ of 1.80 and $0.21 \mathrm{mM}$, respectively. The selectivity of compound 103 on HBeAg inhibition was up to 16.4, which was better than that of positive drug, 3TC, and has a good development prospect [60]. Zeng et al. [61] obtained a quaternary ammonium alkaloid $\mathrm{DHCH}$ (104) from Corydalis saxicola Bunting, which could significantly inhibit the secretion of HBsAg and HBeAg on HepG2.2.15 cells, with TI of 7.32 and 6.77, respectively. Further study showed that compound 104 could reduce the levels of cccDNA and DNA in dose and time dependence manner, with $\mathrm{IC}_{50}$ values of $15.08,7.62$, and $8.25 \mu \mathrm{M}$, respectively. The chemical structures of compounds 98 104 are shown in Figure 7.
2.7. Enediynes. A. capillaris (Yin-Chen) is a famous traditional Chinese medicine (TCM) for treating acute and chronic hepatitis in China [62]. Geng et al. [63] isolated 14 compounds, 8S-deca-9-en-4,6-diyne-1,8-diol (105), $(S)$ deca-4,6,8-triyne-1,3-diol (106), (S)-3-hydroxyundeca5,7,9-triynoic acid (107), 3S-Hydroxyundeca-5,9-triynoic acid 3-O- $\beta$-D-glucopyranoside (108), Atractylodin (109), Dendroarboreol B (110), Dehydrofalcarinol (111), Dehydrofalcarindiol (112), (E)-deca-2-en-4,10-diol (113), $(Z)$-deca2-en-4,10-diol (114), 8-diol 1-O- $\beta$-D-glucopyranoside (115), 3S,8S-dihydroxydec-9-ene-4,6-diyne 1- $O$ - $\beta$-D-glucopyranoside (116), 5-benzylthiophencarboxylic acid (117), and 2-methyl-6-phenyl-4H-pyran-4-one (118), from $A$. capillaris. All the compounds were assayed for their antiHBV activity, and the structure-activity relationships were summarized based on the biological effects. In particular, compound 108 could significantly inhibit the secretions of HBsAg, HBeAg, and HBV-DNA replication with $\mathrm{IC}_{50}$ values of 197.2 (SI > 5.1), $48.7(\mathrm{SI}>20.5)$, and $9.8(\mathrm{SI}>102) \mu \mathrm{M}$. Hydroxyl and glycosyl groups are preferable for maintaining activity. In subsequent studies, Geng et al. [64] found that $3 S, 8 S$-dihydroxydec-9-en-4,6-yne $1-O-\left(6^{\prime}-\mathrm{O}\right.$-caffeoyl $)-\beta$-Dglucopyranoside and 3S,8S-dihydroxydec-9-en-4,6-yne 1-O( $2^{\prime}$-O-caffeoyl)- $\beta$-D-glucopyranoside (119-120) had the activity against the secretions of HBsAg and HBeAg and HBV DNA replication. Especially, compounds 119 and 120 inhibited HBV-DNA replication with $\mathrm{IC}_{50}$ values of 0.077 \pm 0.04 and $0.0127 \pm 0.05 \mathrm{mM}$, with SI values of 23.6 and 17.1, respectively. Compounds $\mathbf{1 1 9}$ and $\mathbf{1 2 0}$ as a pair of isomers showed similar inhibition on HBsAg secretion with $\mathrm{IC}_{50}$ values of $0.797 \pm 0.23 \mathrm{mM}(\mathrm{SI}=2.1)$ and $0.887 \pm 0.20$ $\mathrm{mM}(\mathrm{SI}=2.3$ ), but no activity against HBeAg secretion. Compound 119 displayed the highest inhibitory activity on $\mathrm{HBV}$ DNA replication with an $\mathrm{IC}_{50}$ value of $0.077 \pm 0.04 \mathrm{mM}$ $(\mathrm{SI}=23.6)$, and compound 120 showed slightly decreased activity with an $\mathrm{IC}_{50}$ value of $0.127 \pm 0.05 \mathrm{mM}(\mathrm{SI}=17.1)$. The above analyses suggested that the caffeoyl group played important role in maintaining the anti-HBV activity but the substitution position may not be crucial. The chemical structures of compounds 105 120 are shown in Figure 8.

2.8. Aromatics. Six phenols, $m$-hydroxybenzoic acid (121), $p$ hydroxybenzoic acid (122), $m$-hydroxy benzenmethanol (123), 3,4-dihydroxybenzoic acid (124), ethyl 3,4-dihydroxybenzoate (125), and ethyl 2,5-dihydroxybenzoate (126), exhibited anti-HBV activities by inhibiting $\mathrm{HBsAg}$ and HBeAg secretion with $\mathrm{IC}_{50}$ values from 0.23 to $5.18 \mathrm{mM}$, and HBV-DNA replication with $\mathrm{IC}_{50}$ values from 0.06 to $2.62 \mathrm{mM}$. Compounds 121-123, with one hydroxyl and one carboxyl, showed anti-HBV activity with $\mathrm{IC}_{50}$ values of $3.76,5.18$, and $4.55 \mathrm{mM}$ for inhibitory HBsAg secretion and $2.36,2.54$, and $2.62 \mathrm{mM}$ for inhibitory HBV-DNA replication, respectively. Compounds 124-126 with two hydroxyls and one carboxyl displayed remarkable inhibition on $\mathrm{HBV}$ DNA replication with $\mathrm{IC}_{50}$ values of $<0.06,0.22$, and $0.29 \mathrm{mM}$. Furthermore, compounds 125 and 126 showed significant inhibitory effect on the secretion of $\mathrm{HBsAg}$ $\left(\mathrm{IC}_{50}=0.14\right.$ and $\left.0.23 \mathrm{mM}\right)$ and $\mathrm{HBeAg}\left(\mathrm{IC}_{50}=5.03\right.$ and $3.74 \mathrm{mM}$ ) [34]. 

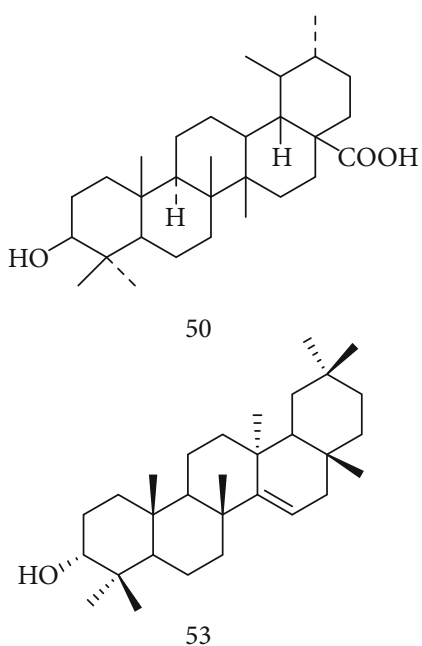

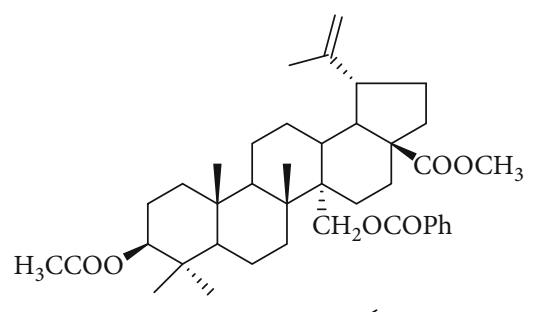<smiles>CC1(C)CC[C@]2(C(=O)O)CC[C@]3(C)C(=CCC4[C@@]5(C)CC[C@H](O)C(C)(C)C5CC[C@]43C)C2C1</smiles>
HO"

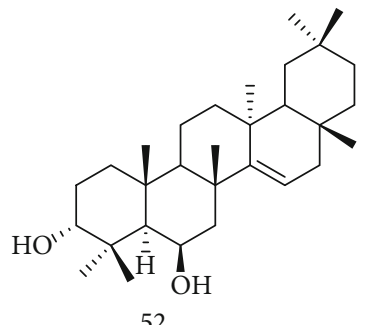<smiles>O=C(O)c1cccc2c1CCOC2=O</smiles>

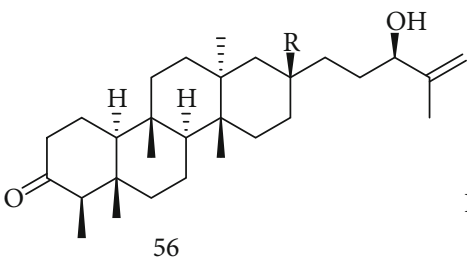<smiles>CC(C)=CCCC1(C)CC[C@]2(C)[C@H]3CC[C@]4(C)C(C)[C@@H](O)CC[C@H]4[C@@]3(C)CC[C@]2(C)C1</smiles><smiles>C[C@H]1C(=O)CC[C@H]2[C@@H]3CC[C@]4(C)C[C@](C)(CCC(=O)O)CC[C@]4(C)[C@H]3CC[C@@]21C</smiles>

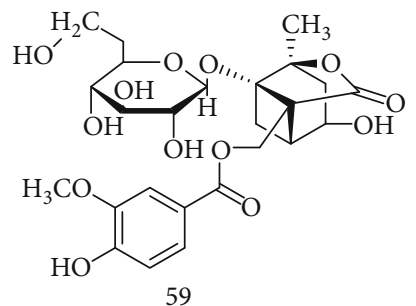

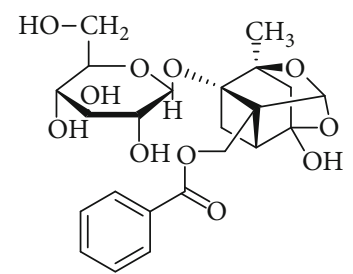

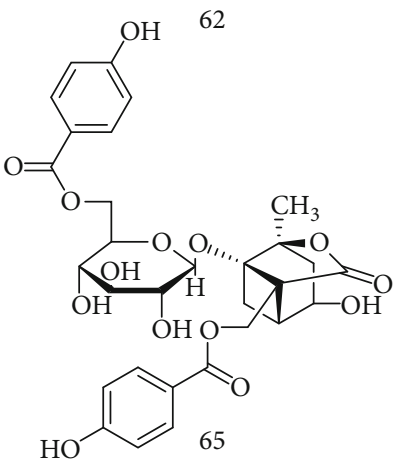

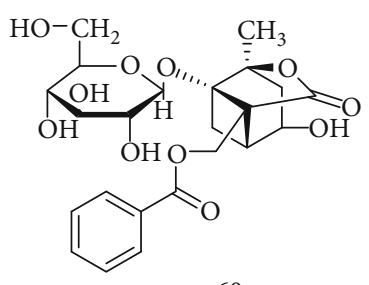

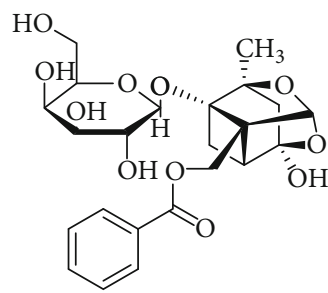

63

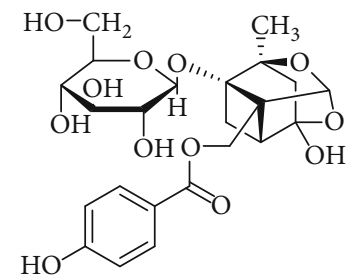

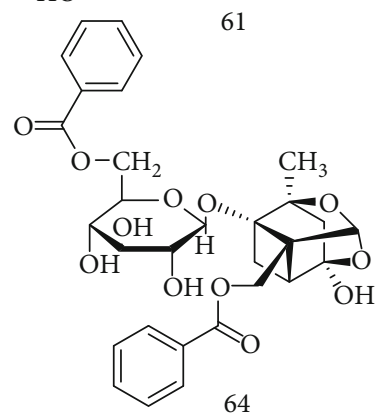<smiles>CC(=O)c1c(O)c(C(C)C)cc2c(c1=O)C[C@]1(O)CCC[C@H](C)[C@H]1CC2</smiles>

(a)

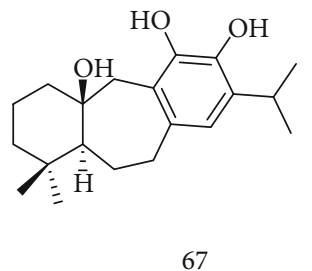

Figure 6: Continued. 


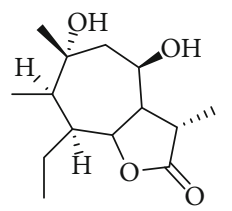

68
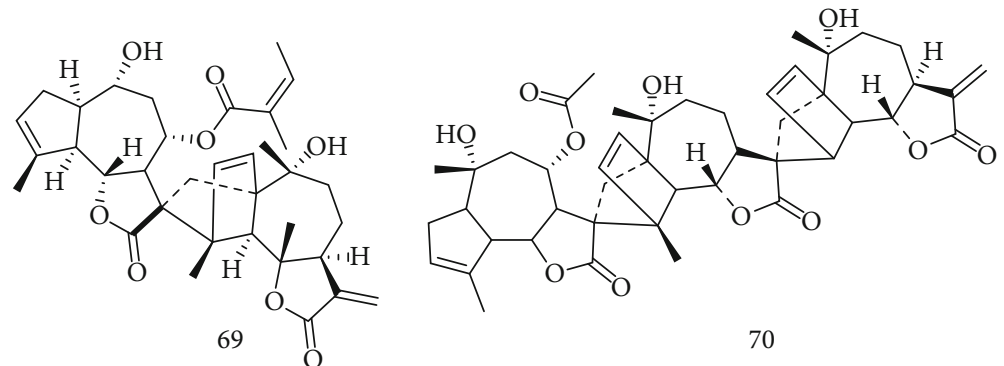

70

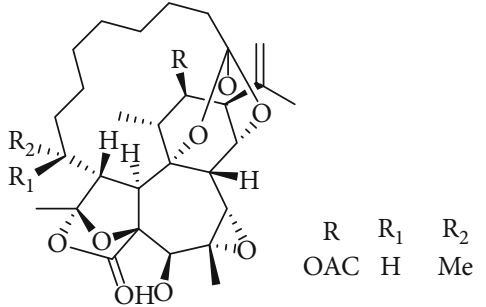

71

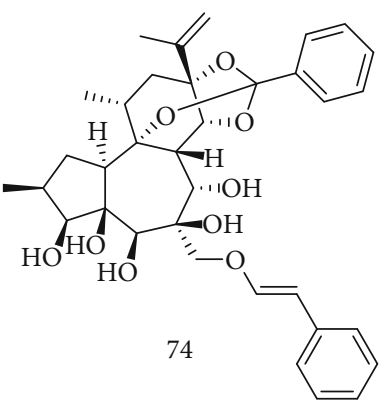

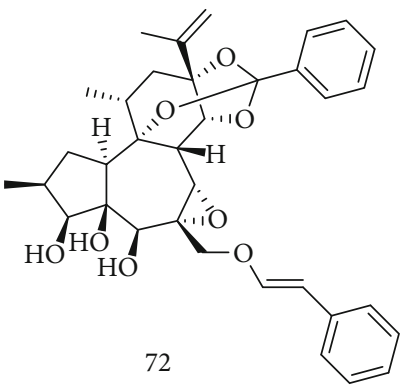

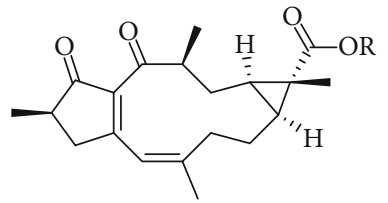

73

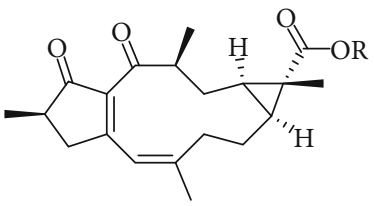

75

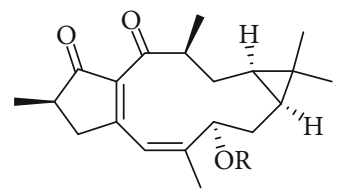

76

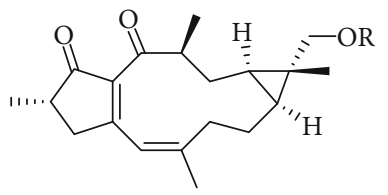

79

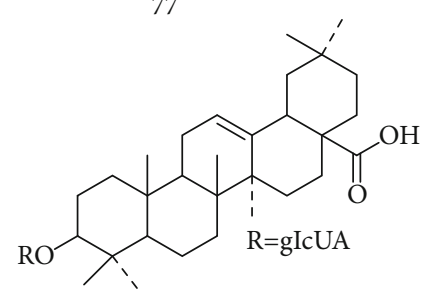

80<smiles>C/C=C1/C2=C(C(=O)OCC2)[C@@H]2OC1C1O[C@@H]2OC(CO)C(O)C1O</smiles>

83

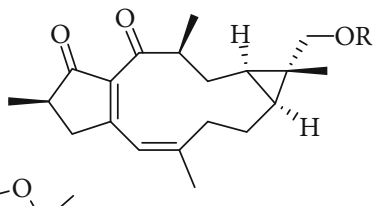

78

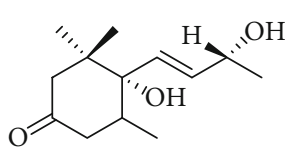

81

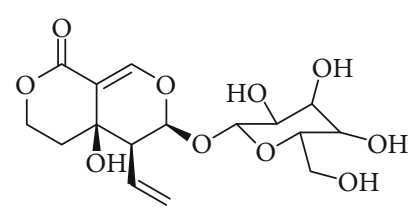

84

(b)<smiles>C[C@H]1CC2=C(C(=O)OCC2)C(OC2OC(O)C(CO)C(O)C2O)O1</smiles>

82<smiles>C=C[C@@H]1C(O)C(O)C(CO)O[C@H]1O[C@H]1OC=C2C(=O)OCC[C@]2(O)[C@@H]1OC(=O)c1cccc(O)c1</smiles>

FIgURE 6: Continued. 
<smiles>C=C[C@]12CCOC(=O)C1=CO[C@H](OC1OC(CO)C(OC(=O)/C=C/c3ccc(OC=O)cc3)C(O)C1O)[C@H]2O</smiles><smiles>C[C@@H]1[C@H]2[C@@H](OC(=O)O)OC=C(C(=O)O)[C@@H]2C[C@H]1OC(=O)c1cccc(O)c1</smiles><smiles>C=CC1C2CCOC(=O)C2=CO[C@H]1OC1OC(O)C(O)C(O)C1O</smiles>

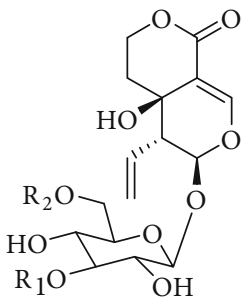<smiles>[R]c1cc(C=CC(C)=O)ccc1O</smiles>
Fer: $\mathrm{R}=\mathrm{OMe}$

R1 R2

88

(E)-Fer<smiles>O=C1OCCc2c(COC(=O)C3CCCCC3)cccc21</smiles>

90<smiles>COc1cccc(/C=C/C(=O)OCc2cccc3c2CCOC3=O)c1</smiles>

91

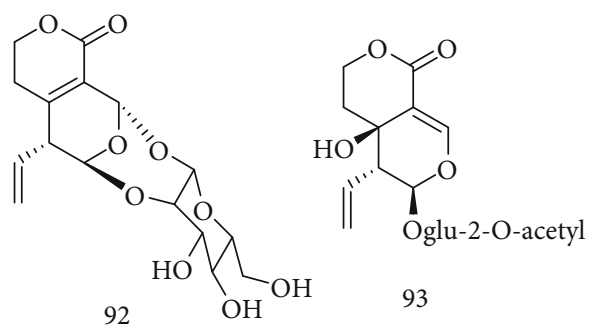

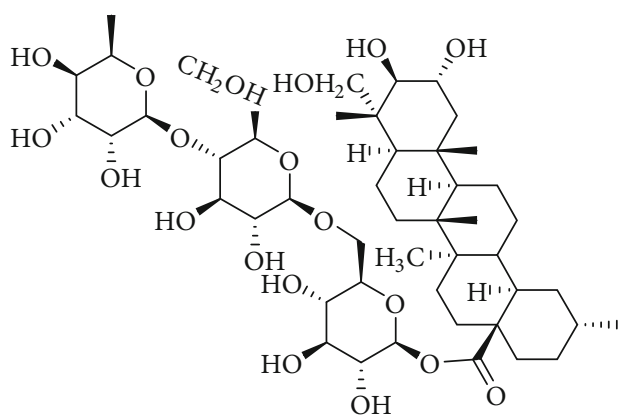

94<smiles>CC(C)[C@H]1CC[C@H]2[C@@H](O)CC[C@@H](C)[C@H]2[C@H]1O</smiles>

96

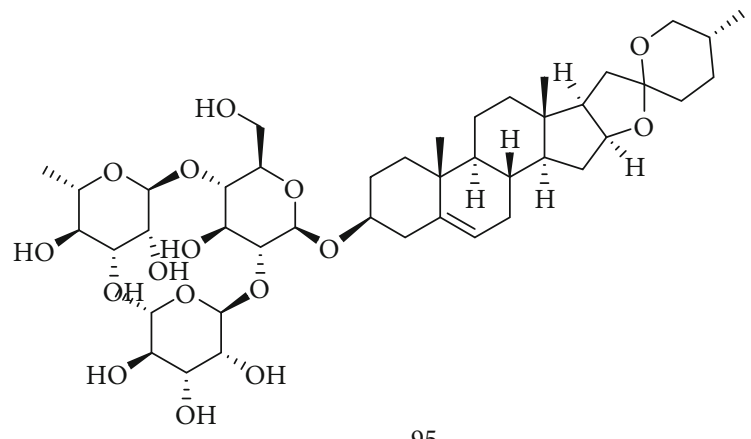

95

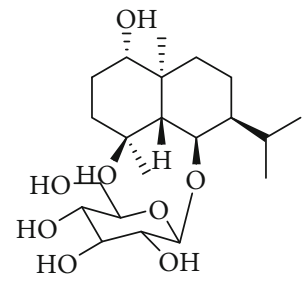

97

(c)

FIgURE 6: Chemical structures of representative anti-HBV terpenes 50-97.

3,3',5-Trihydroxybiphenyl (127), isolated from S. chirayita, showed activity against $\mathrm{HBeAg}$ secretion with IC ${ }_{50}$ values of $0.77 \pm 0.076$ and $5.92 \pm 1.02 \mathrm{mM}$ [27]. Taraffinisoside A (128), descaffeoyl crenatoside (129), and 3,4-dihy-
droxyphenylethanol-8-O-[ $\beta$-D-apiofuranosyl $(1 \rightarrow 3)]-\beta$-Dglucopyranoside (130) isolated from Tarphochlamys affinis (Griff.) could inhibit the secretion of HBsAg and HBeAg [65]. Huang et al. [66] isolated p-hydroxy acetophenone 
<smiles>O=C(/C=C/CCCC[C@@H](O)[C@H](O)c1ccc2c(c1)OCO2)N1CCCCC1</smiles><smiles>O=C(/C=C/C=C/c1ccc2c(c1)OCO2)N1CCCCC1</smiles><smiles>O=C(CCc1ccccc1)N1CC[C@@H](O)[C@H](O)C1=O</smiles><smiles>CCCCCCCCCCCCCCC/C=C/C=C/C(=O)NCC(C)C</smiles><smiles>O=C(/C=C/CCCC[C@H](O)[C@H](O)c1ccc2c(c1)OCO2)N1CCCCC1</smiles><smiles>CC(C)CNC(=O)/C=C/C=C/CC/C=C/c1ccc2c(c1)OCO2</smiles><smiles>COc1cc2c(cc1O)-c1cc3ccc4c(c3c[n+]1CC2)OCO4</smiles>

103

Figure 7: Chemical structures of representative anti-HBV alkaloids 98-104.
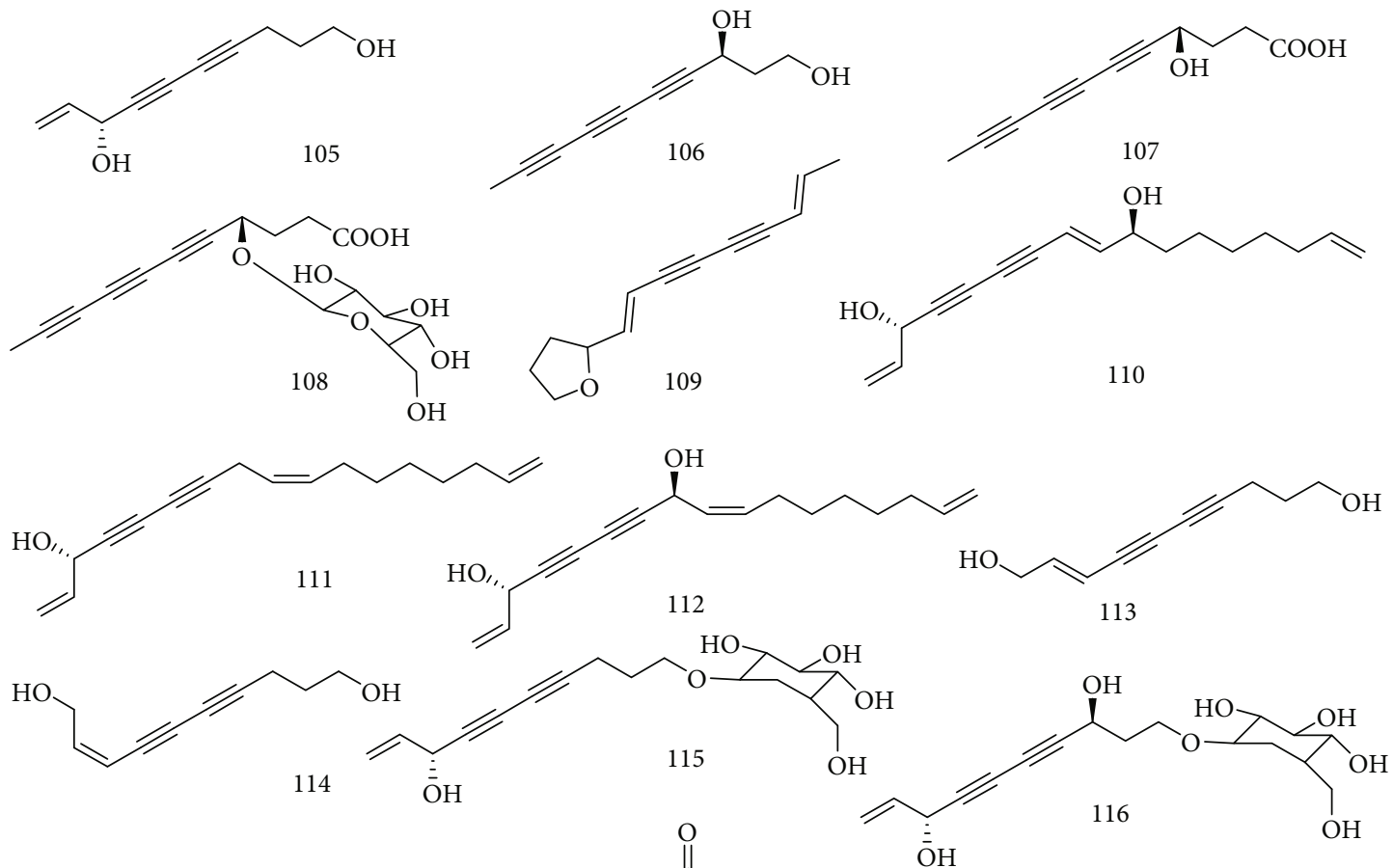<smiles>O=C(O)c1ccc(Cc2ccccc2)s1</smiles><smiles>Cc1cc(=O)cc(-c2ccccc2)o1</smiles><smiles>C/C=C\C(O)C#CC#CC(O)CCOCC(O)C(O)COC(=O)/C=C/c1ccc(O)c(O)c1</smiles><smiles>C=CC(O)C#CC#CC(O)CCOC(OC(=O)/C=C/c1ccc(O)c(O)c1)C(O)(CO)C(O)O</smiles>

FIGURE 8: Chemical structures of representative anti-HBV enediynes 105-120. 
<smiles>O=C(O)c1cccc(O)c1</smiles>

121<smiles>O=C(O)c1ccccc1O</smiles>

124<smiles>Oc1cccc(-c2cc(O)cc(O)c2)c1</smiles>

127

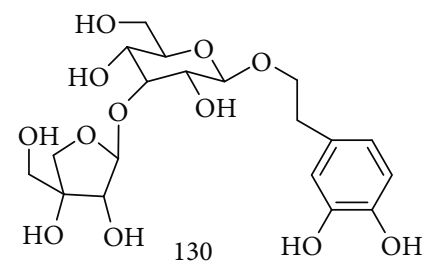<smiles>O=C(O)c1ccc(O)cc1</smiles>

122<smiles>CCOC(=O)c1ccc(O)c(O)c1</smiles>

125

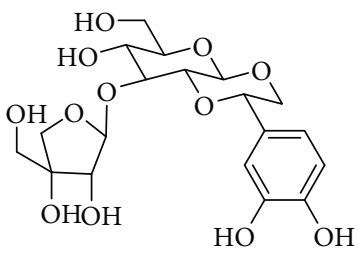

128<smiles>CC(=O)c1ccc(O)cc1</smiles><smiles>OCc1cccc(O)c1</smiles>

123<smiles>CCOC(=O)c1cc(O)ccc1O</smiles>

126

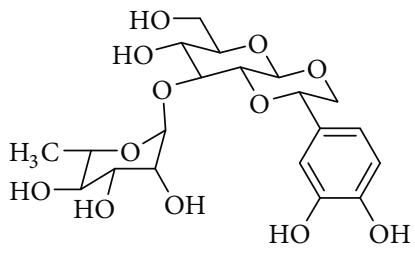

129

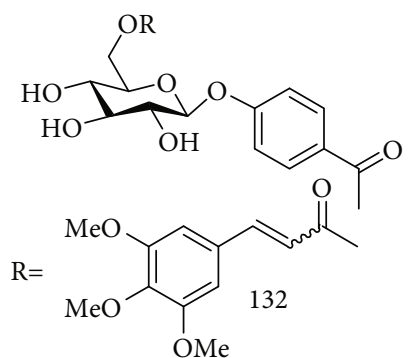

Figure 9: Chemical structures of representative anti-HB Varomatics 121-132.

(PHAP) (131) from A. morrisonensis, which could significantly inhibit the replication of HBV. The mechanism may be that PHAP was involved in regulating the expression of surface protein genes and blocks the release of virus particles by interfering with the signaling pathway of endoplasmic reticulum. Zhao et al. [67] found that PHAP and derivatives have good anti-HBV activity, and structural modification on $\mathrm{p}$-HAP and its glycoside led to a series of derivatives; among them, $p$-HAP derivative $2 \mathrm{f}$ (132) had the strongest effect on inhibiting the replication HBV-DNA $\quad\left(\mathrm{IC}_{50}=5.8 \mu \mathrm{M}, \quad \mathrm{SI}=160.3\right)$. The primary structure-activity relationships suggested that the conjugated derivatives of $p$-HAP glycoside and substituted cinnamic acids obviously enhanced the activity against HBV-DNA replication. The chemical structures of compounds 121 132 are shown in Figure 9.

2.9. Phenylalanine Dipeptides. Yang et al. [68] isolated and modified the phenylalanine dipeptide Matijin-Su (133) with anti-HBV activity from Dichondra repens Forst, and four derivatives were screened with anti-HBV activity in vitro. Yang et al. [69] found that compound 101 could inhibit the replication of $\mathrm{HBV}-\mathrm{DNA}$, with $\mathrm{IC}_{50}$ value of $1.33 \mu \mathrm{M}$, and inhibit the replication of various mutant $\mathrm{HBV}$ strains. $\mathrm{Xu}$ et al. [70] synthesized a series of MTS derivatives with antiHBV activity by the design of the Matijin-Su (MTS). One of the preferred MTS derivatives (Y101) was conducted in the clinical preclinical study and received the clinical approval of the CFDA.

Kuang et al. [71] used the compound MTS as lead compound; a novel MTS derivative was designed and synthesized by introducing the structure unit of veratrol acid; $\mathrm{N}$-[N-(3,4-dimethoxy-benzoyl)-L-phenylalanyl]-O-propionyl-L-phenylalaninol (134), N-[N-(3,4-dimethoxy-benzoyl)-L-phenylalanyl]-4-ethoxy-L-phenylalaninol (135), and N-[N-(3,4-Dimethoxy-benzoyl)-L-phenylalanyl $]-4-$ ethoxycarbonylmethyl-L-tyrosinol (136) were tested the anti-HBV activity in vitro. All the compounds have the significant anti-HBV activity. Subsequently, a series of MTS derivatives were designed and synthesized with compound MTS as the lead compound, by introducing fluorine or chlorine substitution, and the obtained MTS derivatives were tested for anti-HBV activity in vitro. $\mathrm{N}-[\mathrm{N}-(4$-chlorobenzoyl)-O-methyl-L-tyrosyl]-L-Phenylalaninol (137), N[N-(4-chlorobenzoyl)-O-propyl-L-tyrosyl]-L-Phenylalaninol (138), and $\mathrm{N}$-[N-(4-chlorobenzoyl)-O-isopropyl-L-tyrosyl]-L-Phenylalaninol (139) showed good anti-HBV activity, with $\mathrm{IC}_{50}$ of $12.61,10.53$, and $6.46 \mathrm{~mol} / \mathrm{L}$, 


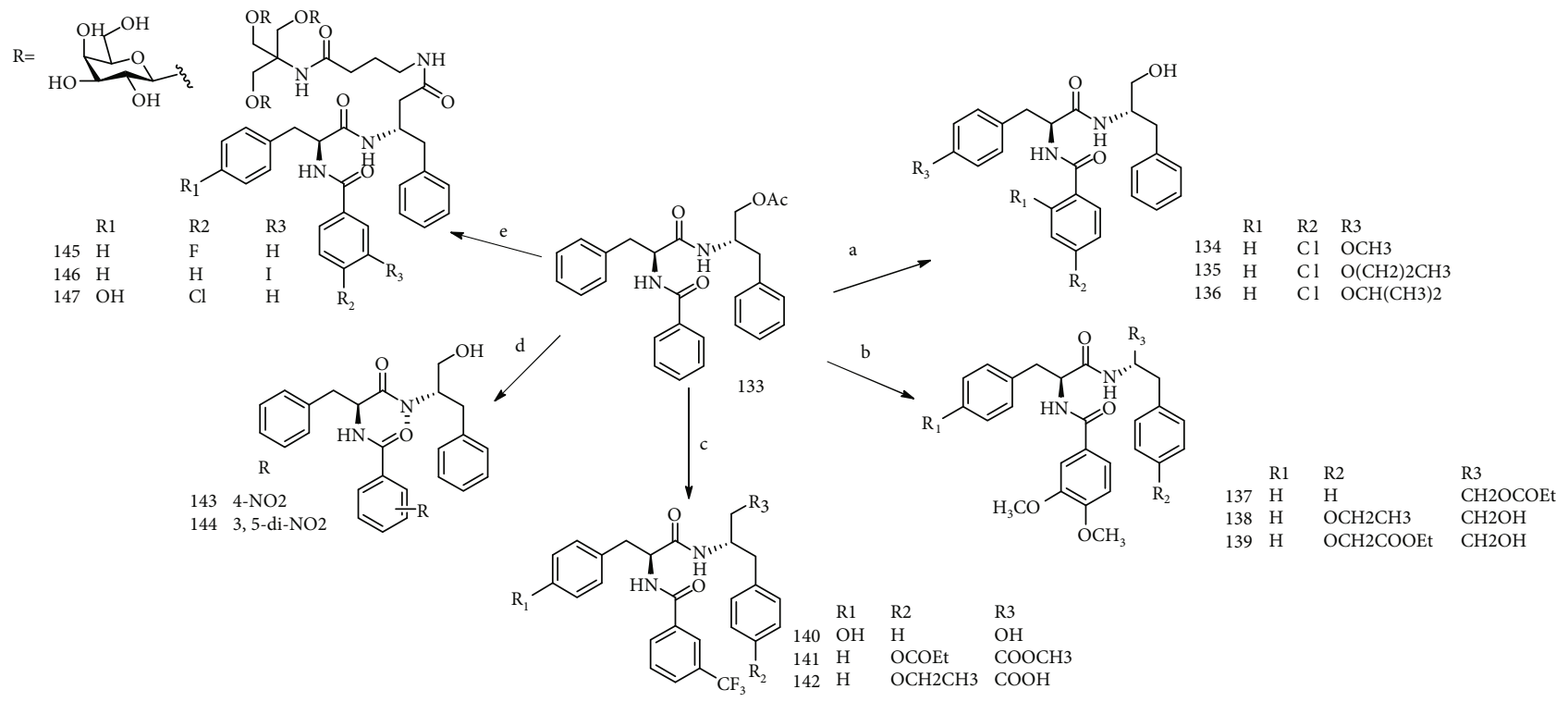<smiles>O=C1CNC(=O)N2CCC[C@H]12</smiles>

148

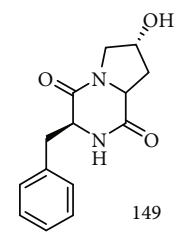

149

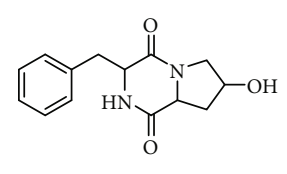

150<smiles>CC(=O)NC(Cc1ccccc1)C(=O)O</smiles>

151

Figure 10: Chemical structures of representative anti-HBV phenylalanine dipeptides 133-151.

respectively [72]. Cui et al. [73] synthesized 20 MTS derivatives containing trifluoromethyl substitution and tested the anti-HBV activity of the synthesized target compound in HepG 2.2.15 cells in vitro. Among them, $\mathrm{N}$-[N-(3-trifluoromethylbenzoyl)-L-tyrosyl]-L-Phenylalaninol (140), $\mathrm{N}$-[N-(3-trifluoromethylbenzoyl)-L-phenylalanyl]-O-propionyl-L-tyrosine methyl ester (141), and $\mathrm{N}$-[N-(3-trifluoromethylbenzoyl)-L-phenylalanyl]-O-ethyl-L-tyrosine (142) showed strong anti-HBV activity, and their $\mathrm{IC}_{50}$ reached $11.74,8.73$, and $11.41 \mathrm{~mol} \cdot \mathrm{L}^{-1}$.

Jang et al. [74] synthesized twenty novel $n$-methyl derivatives of MTS, among which compounds $8 \mathrm{n}(\mathbf{1 4 3})$ and $8 \mathrm{o}$ (144) showed certain anti-HBV activity, with $I_{50}$ of $52.5 \mathrm{~mol} \cdot \mathrm{L}^{-1}$ and $49.2 \mathrm{~mol} \cdot \mathrm{L}^{-1}$, respectively. Compounds $9 \mathrm{a}-$ $c(145-147)$ were triantennary cluster galactosides of MTS with potential for hepatic targeting. The anti-HBV activities of those were evaluated in HepG 2.2.15 cells. And all those compounds had inhibitory effect on HBV-DNA replication in HepG2 2.2.15 cells in a dose-response manner [75]. Huang et al. [76] evaluated the 20 species of marine natural small molecule compounds by HepG 2.2.15 cell lines; three kinds of compounds cyclic (glycine-L-proline) (148), cyclic (4hydroxy proline-phenylalanine) (149), and cyclic (L-2hydroxy proline-phenylalanine) (150) had anti-HBV activity on the inhibition of HBsAg, HBeAg, and HBV-DNA, with the treatment of index greater than 2 . $\mathrm{N}$-acetyl phenylalanine (151) had certain inhibitory effects on HBsAg and $\mathrm{HBeAg}$ with the $\mathrm{IC}_{50}$ values of $55.5,69.5 \mu \mathrm{g} / \mathrm{mL}$, respectively [77]. The chemical structures of compounds 133-151 are shown in Figure 10.

\subsection{Others}

2.10.1. Lactones. Two dimers of oxanthrone andiridoid lactone $(152,153)$ were isolated from S. punicea, which could inhibit the secretion of $\mathrm{HBsAg}$ with $\mathrm{IC}_{50}$ value of 0.25 and $0.29 \mathrm{mM}$, and the secretion of $\mathrm{HBeAg}$ with $\mathrm{IC}_{50}$ value of 0.86 and $0.31 \mathrm{mM}$. In addition, compounds $\mathbf{1 5 2 - 1 5 3}$ also could inhibit the replication of HBV-DNA, with the $\mathrm{IC}_{50}$ values of 0.18 and $0.19 \mathrm{mM}$, respectively [78]. Anislactone $B$ (154), a kind of nor sesquiterpene lactone with unique structure from the fruit of Illicium henryi, had high antiHBV activity and could inhibit the secretion of HBeAg on HepG 2.2.15 cell with $\mathrm{IC}_{50} 0.079 \pm 0.035 \mathrm{mM}$ in vitro [79].

2.10.2. Isosteviol. The analogue of isosteviol, NC-8 (155), had anti-HBV activity by inhibiting the secretion of HBsAg and $\mathrm{HBeAg}$, with the $\mathrm{IC}_{50}$ value of $7.89 \mathrm{~g} / \mathrm{mL}$, which was better than that of the positive control (lamivudine). The mechanism of NC-8 was interfering with HBV replication and gene expression and blocking the TLR2/NF- $\kappa$ b signaling pathway of host cells. It is for the first report of isosteviol analogues against HBV [80]. Huang et al. [81] got a series of new derivatives, including the IN-4 (156) with high anti-HBV activity. The mechanism might be that IN-4 suppressed the expression of HBV gene and the replication of HBV-DNA by interfering with the NF- $\kappa \mathrm{B}$ signaling pathways of host cell.

2.10.3. Organic Acids. Scoparamide A (157) could inhibit not only the secretions of $\mathrm{HBsAg}$ and $\mathrm{HBeAg}$ with $\mathrm{IC}_{50}$ values of $0.617 \pm 0.25 \mathrm{mM}(\mathrm{SI}=2.1)$ and $0.887 \pm 0.25 \mathrm{mM}(\mathrm{SI}=1.4)$, 
<smiles></smiles><smiles>C[C@]12CC[C@]3(O)C(=O)OC[C@H]3[C@@H](O)[C@@]13CC(=O)O[C@@]23C</smiles>

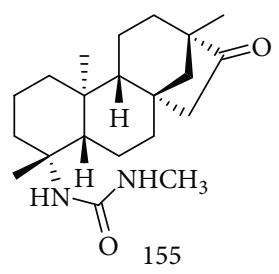

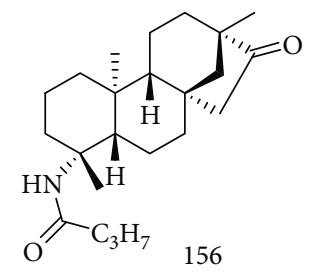<smiles>CCc1cc(=O)cc(CC(CC(=O)O)OC2OC(O)C(O)C(O)C(O)C2O)[nH]1</smiles>

157<smiles>O=C(/C=C/c1ccc(O)c(O)c1)O[C@@H](C(=O)O)[C@H](OC(=O)CCc1ccc(O)c(O)c1)C(=O)O</smiles><smiles>O=C(/C=C/c1ccc(O)c(O)c1)OC(Cc1ccc(O)c(O)c1)C(=O)O</smiles><smiles>O=C(/C=C/c1ccc(O)c(O)c1)O[C@H]1C[C@@](O)(C(=O)O)C[C@H](O)[C@H]1O</smiles>

159

160<smiles>O=C(/C=C/c1ccc(O)c(O)c1)O[C@H]1C[C@@](O)(C(=O)O)C[C@H](O)[C@H]1O</smiles>

161<smiles>O=C(/C=C/c1ccc(O)c(O)c1)O[C@@H]1C[C@](O)(C(=O)O)C[C@H](O)[C@H]1O</smiles>

162<smiles>O=C(/C=C/c1ccc(O)c(O)c1)O[C@H]1C[C@](O)(C(=O)O)C[C@@H](OC(=O)/C=C/c2ccc(O)c(O)c2)[C@@H]1O</smiles>

163<smiles>O=C(/C=C/c1ccc(O)c(O)c1)O[C@H]1C[C@](O)(C(=O)O)C[C@H](O)[C@H]1OC(=O)/C=C/c1ccc(O)c(O)c1</smiles>

164

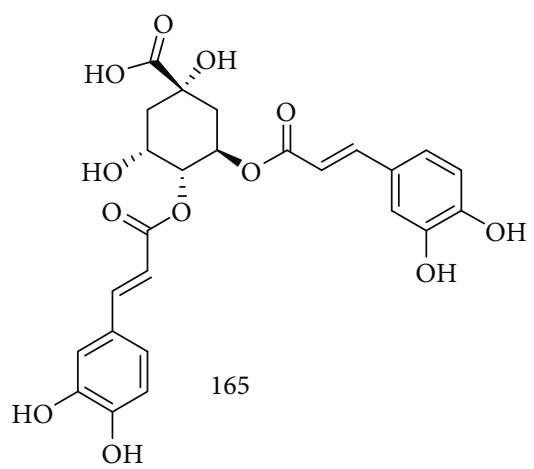

FIgURE 11: Chemical structures of representative anti-HBV compounds 152-165.

respectively, but also $\mathrm{HBV}$-DNA replication with an $\mathrm{IC}_{50}$ value of $0.477 \pm 0.14 \mathrm{mM}$ (SI =2.7) [64]. Zhang et al. [82] isolated cichoric acid (158) from the leaves of Chicory intybus $\mathrm{L}$ and found that it had significant anti-HBV activity. Rosmarinic acid (159) inhibits HBV replication in HBVinfected cells by specifically targeting $\varepsilon$-Pol binding. In addi- tion, they analyzed an additional 25 rosmarinic acid derivatives and found that the "two phenolic hydroxyl groups at both ends" and the "caffeic acid-like structure" of rosmarinic acid are critical for the inhibition of $\varepsilon$-Pol binding [83]. It is well known that phenolic acids have better antiviral activity. The studies showed that 3-caffeoylquinicacid (160) [84] 
could inhibit the secretion of HBsAg, HBeAg, and the replication of HBV-DNA on Hep G 2.2.15 cells at the concentration of $100 \mu \mathrm{g} / \mathrm{mL}$. In order to reveal the anti-HBV activity and structure-activity relationships of the analogues of chlorogenic acid, 9 chlorogenic acid analogues were evaluated on HepG 2.2.15 cell lines in vitro and found that chlorogenic acid, cryptochlorogenic acid (161), neochlorogenic acid (162), 3,5-dicaffeoylquinic acid (163), 4,5-dicaffeoylquinic acid (164), and 3,4-dicaffeoylquinic acid (165) possessed potent activity against $\mathrm{HBV}$-DNA replication with $\mathrm{IC}_{50}$ values in the range of $5.5 \pm 0.9-13.7 \pm 1.3 \mu \mathrm{M}$. Di-caffeoyl analogues (163-165) also exhibited activity against the secretions of HBsAg and HBeAg. The number of caffeoyl moiety may contribute to the inhibitory activity against HBsAg and HBeAg secretions, while the position of caffeoyl units play little role on anti-HBV-DNA activities. In addition, carboxyl group is closely associated to the antiviral activity [85]. The chemical structures of compounds 152 165 are shown in Figure 11.

2.10.4. Polysaccharides. Natural polysaccharide is mainly referred to widely exists in the nature of cellulose and its derivatives, chitin, and other natural polymer materials. Polysaccharides have a wide range of biological activities, such as enhanced immunity, antiviral, and antiinflammatory $[86,87]$.

In recent years, clinical researches of natural polysaccharides on anti-HBV have increased gradually; they have been proved to have significant anti-HBV effect [88]. Lentinan polysaccharide has a prominent effect on antiviral and immune regulation and is also used as an auxiliary drug for cancer and HBV $[89,90]$. Zhao et al. [91] obtain two polysaccharide fractions (LEP-1 and LEP-2) from Lentinus edodes (Berk.) sing. They found that LEPs possess potent anti$\mathrm{HBV}$ activity in vitro. In addition, the polysaccharides from Hedyotis caudatifolia Merr.et Metcalf (50, 100, and $200 \mathrm{mg} / \mathrm{L}$ ) significantly inhibited the secretion and expression of HBV-DNA on HepG 2.2.15 cells and effectively inhibited the secretion of HBsAg and HBeAg. Its mechanism may be related to the activation of JAK/STAT signaling pathway and the promotion of antiviral protein expression [92]. Zhan et al. [93] found that snail polysaccharides have a certain inhibitory effect on the replication of HBV-DNA $(P<0.01)$, which indicated that the maximum inhibition rate of HBsAg and HBeAg in HepG 2.2.15 cells is $42.8 \%$ and $52.1 \%$, respectively, slightly below the positive control group $(P<0.05)$, and the inhibition effect of snail polysaccharide on $\mathrm{HBeAg}$ was better than that of HBsAg. The results of real-time fluorescence quantitative PCR test showed that snail polysaccharide had a certain inhibitory effect on the replication of HBV-DNA $(P<0.011)$. The anti-HBV effect of polyporus polysaccharide may be related to the regulation of the body's immune function, breaking the body's immune tolerance or low state [94]. Angelica sinensis polysaccharide [95] could promote DC mature of HBV transgenic mice, raise its coordinated stimulus molecules on the surface, enhance its promoting lymphocyte proliferation and secretion, strengthen its antigen oral ability, induce cellular immune response, reduce serum concentrations of HBsAg, and play a role in antiviral immunity. Liu et al. [96] extracted Chinese whelk polysaccharide by water extraction and transfected human hepatocellular carcinoma cells with HBVDNA cloning as an experimental model. The results showed that PCC significantly inhibited HBV-DNA in HepG 2.2.15 cells at $0.1 \mathrm{mg} \cdot \mathrm{mL}^{-1}$ and $1 \mathrm{mg} \cdot \mathrm{mL}^{-1}$. Xia et al. [97] investigated the effect of polysaccharides of Sipunculus nudus Linnaeus on anti-HBV; the results showed that polysaccharide with different dose groups were different degree of inhibition of HBV-DNA replication $(P<0.05)$, and the effects of high, middle dose group were similar to acyclovir.

\section{Conclusion and Perspectives}

At present, a variety of natural products with novel structure and high anti-HBV activity were isolated from natural resources. Among them, we found that terpenoids with antihepatitis B activity are the most (Figure 6 and Table 1), and the activity is more significant.

However, the research content were disorderly and mainly focus on the simple isolation and identification of anti-HBV activity ingredients; the in-depth studies of antiHBV mechanisms and targets are relatively rare. Moreover, most of the studies are limited to cell level, lack of animal model experiments, and no in-depth research of ingredients with significant antihepatitis B activity. Therefore, there are three suggestions for product research and development:

3.1. Search for New Natural Product Resources. The research on natural products against hepatitis B mainly focuses on the field of traditional Chinese medicine on land. The research on traditional Chinese medicine against hepatitis $b$ has been very matured. However, it is still difficult to develop active natural products against HBV. In addition, there are few researches on marine natural products, microbial fermentation products, plant polysaccharides, and other aspects. In recent years, studies have found that marine natural products have good biological activity due to their special growth environment. Huang et al. [76] screened significant anti-HBV active ingredients from small marine molecules. Microbial fermentation products are a novel source of natural products. In recent years, many novel compounds are derived from microbial fermentation products. It is an interesting way to study the anti-HBV activity of microbial fermentation products. Plant polysaccharides have a wide range of biological activities, and studies [88-95] have shown that the chemical components of polysaccharides have a good anti-HBV activity. It is of great significance to search for anti-HBV active ingredients from novel natural products.

3.2. Novel Method for Screening. The traditional screening of anti-HBV activity involves the separation and identification of chemical components in traditional Chinese medicinal materials and then the screening of their activity, which often takes time and effort and is difficult to obtain accurate screening results. In recent years, researchers used computer-aided drug design (molecular simulation docking) to screen out suitable compounds from the database and then carried out screening in vitro. This method has strong purpose and high 
accuracy. A series of derivatives with good anti-HBV activity were obtained by modifying the structure of known compounds with anti-HBV activity, and the derivatives with the best activity were screened out through activity test. This method also provides a new idea for discovering anti-HBV compounds with better activity [71-75].

3.3. Synergy Effect. Single-chemical components of natural products are no longer effective against $\mathrm{HBV}$, and drug resistance will appear. For example, artemisinin is combined with other components to fight malaria. In anti$\mathrm{HBV}$ studies, treatment methods of combination drugs are also widely used [98].

\section{Data Availability}

The data used to support the findings of this study are available from the corresponding author upon request.

\section{Conflicts of Interest}

The authors declare no conflict of interest.

\section{Authors' Contributions}

All authors contributed to the manuscript. W.K. and Z.L. conceived this subject. X.L. and C.M. searched, collected, and analyzed the relevant literature, as well as prepared the first draft. W.K. and X.L. critically read and revised the paper. All authors read and approved the final manuscript.

\section{Acknowledgments}

This work was supported by the Key Project in Science and Technology of Henan Province (182102410083).

\section{References}

[1] C. Wohlfarth and T. Efferth, "Natural products as promising drug candidates for the treatment of hepatitis B and C," Acta Pharmacologica Sinica, vol. 30, no. 1, pp. 25-30, 2009.

[2] M. Safioleas, N. J. Lygidakis, and C. Manti, "Hepatitis B today," Hepato-Gastroenterology, vol. 54, no. 74, pp. 545-548, 2007.

[3] World Health Organisation, "Hepatitis B, factsheet, No.204," 2014, https://www.who.int/Mediacentre/factsheets/fs204/en/ 1.

[4] W. S. Mason, Cancer Associated Viruses, Springer-Verlag New York Inc., New York, 2012.

[5] M. Nassal, "New insights into HBV replication: new opportunities for improved therapies," Future Virology, vol. 4, no. 1, pp. 55-70, 2009.

[6] Y. T. Li, J. W. Huang, R. A. Xu, and X. L. Cui, "Progress in recent study of anti-HBV natural products and extracts," Mini-reviews in Organic Chemistry, vol. 10, no. 3, pp. 241253, 2013.

[7] M. Z. Cai and G. Qin, "Research advances in anti-hepatitis B virus drugs," Clinical Gastroenterology and Hepatology, vol. 35, no. 10, pp. 2302-2307, 2019.

[8] Z. C. Xu, K. T. Zhao, and Y. A. Jiang, "Development of antiviral drugs against hepatitis B virus (in Chinese)," Chinese Science Bulletin, vol. 64, pp. 3123-3141, 2019.
[9] H. Ahmed, M. K. P. Arbab, S. A. D. Mohammed, and J. A. R. Adnan, "In vitro evaluation of novel antiviral activities of 60 medicinal plants extracts against hepatitis B virus," Experimental and Therapeutic Medicine, vol. 14, pp. 626-634, 2017.

[10] Z. H. Duan and X. M. Chen, "Research progress on the active constituents of Chinese traditional medicine for anti HBV," Journal of Liaoning University, vol. 18, no. 11, pp. 112-115, 2016.

[11] X. C. Yao, X. Xiao, B. K. Huang, and Z. Y. Xu, "Molecular docking and in vitro screening of active anti-hepatitis $B$ virus components from Abrus cantoniensis," The Chinese Journal of Clinical Pharmacology, vol. 35, no. 5, pp. 439-441, 2019.

[12] Y. T. Li, R. A. Xu, and X. L. Cui, "Progress in anti-hepatitis B virus natural drugs targeting different sites," Chinese Journal of Pharmacology and Toxicology, vol. 26, no. 5, pp. 702-705, 2012.

[13] S. P. Tong, J. S. Li, and J. R. Wands, "Affecting B virus genetic conventions: biological properties and clinical implications," Emerging Microbes and Infections, vol. 2, no. 3, pp. 1-11, 2019.

[14] Y. L. Wang, R. X. Wang, and W. B. Hou, "Anti-viral components of natural products," Natural Product Research and Development, vol. 19, pp. 179-182, 2007.

[15] J. Chen and J. M. Wu, "Advances in the structure and function of HBV open reading frame," International Journal of Digestive Diseases, vol. 28, no. 2, pp. 114-116, 2008.

[16] D. Grimm, R. Thimme, and H. E. Blum, "HBV life cycle and novel drug targets," Hepatology International, vol. 5, no. 2, pp. 644-653, 2011.

[17] S. Urban, A. Schulze, and M. Dandri, "The replication cycle of hepatitis B virus," Journal of Hepatology, vol. 52, no. 2, pp. 282-284, 2010.

[18] D. Hu, G. W. Wei, and Z. Y. Qu, "Research progress on hepatoprotective effects of Schissandra chinensis," Journal of Pharmaceutical Research, vol. 38, no. 4, pp. 229-232, 2019.

[19] L. Q. Li, J. Li, and Y. Huang, "Lignans from the heartwood of Streblus asper and their inhibiting activities to Hepatitis B virus," Fitoterapia, vol. 83, no. 2, pp. 303-309, 2012.

[20] S. X. Huang, J. F. Mou, Q. Luo, Q. H. Mo, and X. L. Zhou, "Anti-hepatitis B virus activity of esculetin from Microsorium fortunei in vitro and in vivo," Molecules, vol. 24, no. 19, p. 3475, 2019.

[21] H. Chen, J. Li, and Q. Wu, "Anti-HBV activities of Streblus asper and constituents of its roots," Fitoterapia, vol. 83, no. 4, pp. 643-649, 2012.

[22] J. Li, A. P. Meng, X. L. Guan, and J. Li, “Anti-hepatitis B virus lignans from the root of Streblus asper," Bioorganic \& Medicinal Chemistry Letters, vol. 23, no. 7, pp. 2238-2244, 2013.

[23] J. Li, Y. Huang, X. L. Guan, and J. Li, “Anti-hepatitis B virus constituents from the stem bark of Streblus asper," Phytochemistry, vol. 82, pp. 100-109, 2012.

[24] W. Su, J. P. Zhao, M. Yang, H. W. Yan, and T. Pang, "A coumarin lignanoid from the stems of Kadsura heteroclita," Bioorganic \& Medicinal Chemistry Letters, vol. 25, no. 7, pp. 15061508, 2015.

[25] S. Liu, W. X. Wei, K. Shi, X. Cao, and M. Zhou, "In vitro and in vivo anti-hepatitis $\mathrm{B}$ virus activities of the lignan niranthin isolated from Phyllanthus niruri L.," Journal of Ethnopharmacology, vol. 155, no. 2, pp. 1061-1067, 2014.

[26] K. He, C. A. Geng, T. W. Cao, H. L. Wang, and Y. B. Ma, “Two new secoiridoids and other anti-hepatitis $\mathrm{B}$ virus active 
constituents from Swertia patens," Journal of Asian Natural Products Research, vol. 18, no. 6, pp. 528-534, 2016.

[27] N. J. Zhou, C. A. Geng, X. Y. Huang, and Y. B. Ma, “Anti-hepatitis B virus active constituents from Swertia chirayita," Fitoterapia, vol. 100, pp. 27-34, 2015.

[28] W. S. Yi, "Research progress of flavonoids biological activity," Guangzhou Chemical Industry, vol. 40, no. 2, pp. 47-50, 2012.

[29] H. L. Wang, C. A. Geng, Y. B. Ma, and X. M. Zhang, "Three new secoiridoids, swermacrolactones A-C and anti-hepatitis B virus activity from Swertia macrosperma," Fitoterapia, vol. 89, pp. 183-187, 2013.

[30] T. W. Cao, C. A. Geng, and F. Q. Jiang, "Chemical constituents of Swertia yunnanensis and their anti-hepatitis B virus activity," Fitoterapia, vol. 89, pp. 175-182, 2013.

[31] T. J. Huang, Y. C. Tsai, S. Y. Chiang, and G. J. Wang, "Antiviral effect of a compound isolated from Liriope platyphylla against hepatitis B virus in vitro," Virus Research, vol. 192, pp. 16-24, 2014.

[32] M. K. Parvez, M. R. Tabish, P. Alam, and M. S. Al-Dosari, "Plant-derived antiviral drugs as novel hepatitis B virus inhibitors: cell culture and molecular docking study," Saudi Pharmaceutical Journal, vol. 27, no. 3, pp. 389-400, 2019.

[33] M. Mathayan, S. Jayaraman, L. Kulanthaivel, and A. Suresh, "Inhibition studies of HBV DNA polymerase using seed extracts of Pongamia pinnata," Bioinformation, vol. 15, no. 7, pp. 506-512, 2019.

[34] T. W. Cao, C. A. Geng, Y. B. Ma, X. M. Zhang, and J. Zhou, "Chemical constituents of Swertia mussotii and their antihepatitis B virus activity," Fitoterapia, vol. 102, pp. 15-22, 2015.

[35] D. Y. Xiao, Experimental Research of Epimedium Hyde II AntiHBV In Vivo and In Vitro[D], Zunyi Medical University, 2018.

[36] T. W. Cao, C. A. Geng, Y. B. Ma, K. He, and H. L. Wang, "Xanthones with anti-hepatitis B virus activity from Swertia mussotii," Planta Medica, vol. 79, no. 8, pp. 679-700, 2013.

[37] S. D. Qin, Y. Wang, W. Wang, and W. M. Zhu, “Anti-H1N1virus secondary metabolites from mangrove-derived aciduric fungus Penicillium sp. OUCMDZ-4736," Chinese Journal of Marine Drugs, vol. 35, pp. 21-28, 2016.

[38] T. W. CAO, C. A. GENG, Y. B. MA, and K. HE, "Chemical constituents of Swertia delavayi and their anti-hepatitis B virus activity," China Journal of Chinese Materia Medica, vol. 40, no. 5, pp. 897-902, 2015.

[39] Z. L. Bu, C. M. Yu, W. Y. Lin, P. Z. Hong, and Y. Li, "Research progress on the synthesis of anthraquinones," Chinese Journal of Synthetic Chemistry, vol. 9, pp. 747-762, 2019.

[40] Z. Peng, G. Fang, F. H. Peng, Z. Y. Pan, and Z. Y. Su, "Effects of Rubiadin isolated from Prismatomeris connata on antihepatitis B virus activity in vitro," Phytotherapy Research, vol. 31, no. 12, pp. 1962-1970, 2017.

[41] M. K. Parvez, M. S. Al-Dosari, P. Alam, M. T. Rehman, and M. F. Alajmi, "The anti-hepatitis B virus therapeutic potential of anthraquinones derived from Aloe vera," Phytotherapy Research, vol. 33, no. 11, pp. 2960-2970, 2019.

[42] T. Y. Lan, Research on Anti-HBV Effect and Mechanism of Hypericin, KunMing University of Science and Technology, 2016.

[43] J. H. Zhang, W. T. Liu, and H. M. Luo, "Advances in activities of terpenoids in medicinal plants," Modernization of Traditional Chinese Medicine and Materia Medica-World Science and Technology, vol. 3, pp. 419-430, 2018.
[44] Q. F. Huang, R. B. Huang, L. Wei, and Y. X. Chen, “Antiviral activity of methyl helicterate isolated from Helicteres angustifolia (Sterculiaceae) against hepatitis B virus," Antiviral Research, vol. 100, no. 2, pp. 373-381, 2013.

[45] W. B. Zhou, G. Z. Zeng, H. M. Xu, W. J. He, and N. H. Tan, "Astataricusones A-D and astataricusol A, five new antiHBV shionane-type triterpenes from Aster tataricus 1. f," Molecules, vol. 18, no. 12, pp. 14585-14596, 2013.

[46] W.-B. Zhou, G.-Z. Zeng, H.-M. Xu, W.-J. He, Y.-M. Zhang, and N.-H. Tan, "Astershionones A-F, six new anti-HBV shionane-type triterpenes from Aster tataricus," Fitoterapia, vol. 93, pp. 98-104, 2014.

[47] M. Bi, C. Tang, and H. Yu, "Monoterpenes from paeonia sinjian gensis inhibit the replication of hepatitis B virus," Records of Natural Products, vol. 7, no. 4, pp. 346-350, 2013.

[48] Z. Y. Jiang, C. G. Huang, H. B. Xiong, and K. Tian, "Perovskatone A: a novel $\mathrm{C}_{23}$ terpenoid from Perovskia atriplicifolia," Tetrahedron Letters, vol. 54, no. 29, pp. 3886-3888, 2013.

[49] Q. Gu, Y. Chen, H. Cui et al., "Chrysanolide A, an unprecedented sesquiterpenoid trimer from the flowers of Chrysanthemum indicum L," RSC Advances, vol. 3, no. 26, pp. 10168-10172, 2013.

[50] P. Y. Hayes, S. Chow, M. J. Somerville, J. J. D. Voss, and M. T. Fletcher, "Pimelotides A and B, diterpenoid ketal-lactone orthoesters with an unprecedented skeleton from Pimelea elongate," Journal of Natural Products, vol. 72, no. 12, 2009.

[51] Z. Q. Zhang, S. F. Li, L. W. Zhang, and J. B. Chao, "Chemical constituents from flowers of Wikstroemia chamaedaphne and their anti-hepatitis B virus activity," Chinese Traditional and Herbal Drugs, vol. 48, no. 7, 2017.

[52] J. B. Fang, Y. W. Liu, Y. W. Zhang, J. Teng, and H. Q. Duan, "Antivirus constituents from Alternanthera philoxeroides," Chinese Traditional and Herbal Drugs, vol. 38, no. 7, 2007.

[53] X.-X. Jie, C.-A. Geng, X.-Y. Huang et al., "Five new secoiridoid glycosides and one unusual lactonic enol ketone with antiHBV activity from Swertia cincta," Fitoterapia, vol. 102, pp. 96-101, 2015.

[54] C. A. Geng, X. Y. Huang, Y. B. Ma, X. M. Zhang, and J. J. Chen, "Synthesis of erythrocentaurin derivatives as a new class of hepatitis B virus inhibitors," Bioorganic \& Medicinal Chemistry Letters, vol. 25, no. 7, pp. 1568-1571, 2015.

[55] Q. F. Huang, S. J. Zhang, R. B. Huang, W. Ling, and Y. X. Chen, "Isolation and identification of an anti-hepatitis B virus compound from Hydrocotyle sibthorpioides Lam," Journal of Ethnopharmacology, vol. 150, no. 2, pp. 568-575, 2013.

[56] C. Liu, Y. Wang, and C. Wu, "Dioscin's antiviral effect in vitro," Virus Research, vol. 172, no. 1-2, pp. 9-14, 2013.

[57] Y. Zhao, C. A. Geng, C. L. Sun, Y. B. Ma, X. Y. Huang, and T. W. Cao, "Polyacetylenes and anti-hepatitis B virus active constituents from Artemisia capillaris," Fitoterapia, vol. 95, pp. 187-193, 2014.

[58] Z. Xu, D. L. Wu, W. Zhang, and F. A. Ma, "Advances in studies on alkaloids compounds," Guangdong Chemical Industry, vol. 17, pp. 84-85, 2014.

[59] Z.-Y. Jiang, W.-F. Liu, X.-M. Zhang, J. Luo, Y.-B. Ma, and J.J. Chen, "Anti-HBV active constituents from Piper longum," Bioorganic \& Medicinal Chemistry Letters, vol. 23, no. 7, pp. 2123-2127, 2013.

[60] Z. Y. Jiang, W. F. Liu, C. G. Huang, and X. Z. Huang, "New amide alkaloids from Piper longum," Fitoterapia, vol. 84, no. 3, pp. 222-226, 2013. 
[61] F. L. Zeng, Y. F. Xiang, Z. R. Liang, X. Wang, D. E. Huang, and S. N. Zhu, "Anti-hepatitis B virus effects of dehydrocheilanthifoline from Corydalis saxicola," Journal of Chinese Medicine, vol. 41, no. 1, pp. 119-130, 2013.

[62] Y. P. Liu, X. Y. Qiu, Y. Liu, and G. Ma, "Research progress on pharmacological effect of Artemisiae Scopariae Herba," Chinese Traditional and Herbal Drugs, vol. 9, pp. 2235-2241, 2019.

[63] C. A. Geng, T. H. Yang, X. Y. Huang, J. I. Yang, Y. B. Ma, and T. Z. Li, "Anti-hepatitis B virus effects of the traditional Chinese herb Artemisia capillaris and its active enynes," Journal of Ethnopharmacology, vol. 10, pp. 283-289, 2018.

[64] C.-A. Geng, X.-Y. Huang, X.-L. Chen et al., "Three new antiHBV active constituents from the traditional Chinese herb of Yin-Chen (Artemisia scoparia)," Journal of Ethnopharmacology, vol. 176, no. 12, pp. 109-117, 2015.

[65] X. L. Zhou, Q. W. Wen, X. Lin, S. J. Zhang, and Y. X. Li, “A new phenylethanoid glycoside with antioxidant and antiHBV activity," Archives of Pharmacal Research, vol. 37, no. 5, pp. 600-605, 2014.

[66] T. J. Huang, S. H. Liu, Y. C. Kuo, C. W. Chen, and S. H. Chou, "The Antiviral activity of chemical compound isolated from Artemisia morrisonensis against hepatitis B virus in vitro," Antiviral Research, vol. 10, no. 1, pp. 97-104, 2014.

[67] Y. Zhao, C.-A. Geng, H. Chen et al., "Isolation, synthesis and anti-hepatitis B virus evaluation of_p_-hydroxyacetophenone derivatives from Artemisia capillaris," Bioorganic \& Medicinal Chemistry Letters, vol. 25, no. 7, pp. 1509-1514, 2015.

[68] X. X. Yang, P. X. Cao, Z. M. Huang, and G. Y. Liang, "Synthesis and anti-hepatitis B virus activities of Matijin-Su derivatives," Central South Pharmacy, vol. 12, no. 2, pp. 97-102, 2014.

[69] L. Yang, L.-p. Shi, H.-j. Chen et al., "Isothiafludine, a novel non-nucleoside compound, inhibits hepatitis B virus replication through blocking pregenomic RNA encapsidation," Acta Pharmacologica Sinica, vol. 35, no. 3, pp. 410-418, 2014.

[70] B. X. Xu, Z. M. Huang, C. X. Liu, and Z. G. Cai, "Synthesis and anti-hepatitis B virus activities of Matijing-Su derivatives," Bioorganic \& Medicinal Chemistry, vol. 17, no. 8, pp. 31183125, 2009.

[71] A. X. Kuang, W. Lu, X. P. Zeng, G. Y. Liang, and B. X. Xu, "Synthesis and anti-HBV activity evaluation of Matijin-Su derivatives containing veratric acid," Chinese Journal of New Drugs, vol. 28, no. 12, 2019.

[72] A. X. Kuang, X. P. Zeng, P. Cao, G. Y. Liang, and B. X. Xu, "Synthesis and anti-HBV activity evaluation of fluorine or chlorine-substituted derivatives of Matijin-Su," Journal of Guizhou Medical University, vol. 4, no. 4, pp. 418-422, 2019.

[73] J. Cui, W. Lu, J. Y. Qiu, X. P. Zeng, G. Y. Liang, and B. X. Xu, "Synthesis and anti-HBV activity evaluation of Matijin-Su derivatives containing trifluoromethyl," Chinese Pharmaceutical Journal, vol. 54, no. 13, 2019.

[74] X. Y. Jang, X. P. Zeng, K. X. Wei, G. Y. Liang, and B. X. Xu, "Synthesis and anti-HBV activities of novel N-methylated derivatives of MTS," Chinese Journal of Synthetic Chemistry, vol. 27, no. 4, pp. 244-252, 2019.

[75] C. Zhou, G. C. Xu, Z. X. Hu, X. P. Zeng, Q. C. Liu, and J. Yuan, "Synthesis and anti-HBV activities of MTS derivatives of novel triantennary cluster galactoside," Chinese Journal of Synthetic Chemistry, vol. 26, no. 3, pp. 160-167, 2018.

[76] X. X. Meng, S. Z. Wu, L. Yang, C. Cui, and Z. J. Cen, "Screening of marine natural active small molecules against hepatitis $\mathrm{B}$ virus," Modern Preventive Medicine, vol. 45, no. 23, pp. 4335-4340, 2018.

[77] H. N. Wang, Z. F. Yin, X. Yin, H. B. Li, and G. Q. Zhao, "Chemical constituents from Pogonatherum crinitum and their anti-HBV activities in vitro," Chinese Traditional Patent Medicine, vol. 41, no. 6, 2019.

[78] H.-L. Wang, T.-W. Cao, F.-Q. Jiang et al., "Swerpunilactones A and $\mathrm{B}$, the first example of xanthone and secoiridoid heterodimers from Swertia punicea, S. hispidicalyx, and S. yunnanensis," Tetrahedron Letters, vol. 54, no. 21, pp. 27102712, 2013.

[79] J. F. Liu, Y. F. Wang, Y. P. Bi, H. J. Li, and L. Jia, "Unusual norsesquiterpene lactone from the fruits of Illicium henryi," Tetrahedron Letters, vol. 54, no. 36, pp. 4834-4836, 2013.

[80] T. J. Huang, B. H. Chou, C. W. Lin, and J. H. Weng, "Synthesis and antiviral effects of isosteviol-derived analogues against the hepatitis B virus," Phytochemistry, vol. 99, no. 1, pp. 107-114, 2014.

[81] T.-J. Huang, C.-L. Yang, Y.-C. Kuo et al., "Synthesis and antihepatitis B virus activity of $\mathrm{C} 4$ amide-substituted isosteviol derivatives," Bioorganic \& Medicinal Chemistry, vol. 23, no. 4, pp. 720-728, 2015.

[82] H.-L. Zhang, L.-H. Dai, Y.-H. Wu et al., "Evaluation of hepatocyteprotective and anti-hepatitis B virus properties of Cichoric acid from Cichorium intybus leaves in cell culture," Biological \& Pharmaceutical Bulletin, vol. 37, no. 7, pp. 1214-1220, 2014.

[83] Y. Tsukamoto, S. Ikeda, K. Uwai, R. Taguchi, K. Chayama, and T. Sakaguchi, "Rosmarinic acid is a novel inhibitor for hepatitis B virus replication targeting viral epsilon RNA-polymerase interaction," PLoS One, vol. 13, no. 5, article e0197664, 2018.

[84] Q. Yang, J. M. Li, H. Q. Wan, L. L. Ge, X. B. Zeng, and S. S. Peng, "Anti-HBV activities of extracts and 3-caffeolquinic acid from Lonicera japonica Flower BudsJ," Wuhan University Journal of Natural Sciences, vol. 65, no. 4, pp. 352-356, 2019.

[85] Y. Zhao, C.-A. Geng, Y.-B. Ma et al., "UFLC/MS-IT-TOF guided isolation of anti-HBV active chlorogenic acid analogues from Artemisia capillaris as a traditional Chinese herb for the treatment of hepatitis," Journal of Ethnopharmacology, vol. 156, pp. 147-154, 2014.

[86] X. T. Zhu, "Research progress on the bioactivity of plant polysaccharide," Journal of Anhui Agricultural Sciences, vol. 28, pp. 12076-12077, 2008.

[87] S. Y. Chen, W. J. Liu, Q. N. Cao, and C. J. Ao, "Research advancement in bioactivity of polysaccharides from plants," Feed Industry, vol. 22, pp. 60-64, 2016.

[88] X. B. Qin, "Advances in the research of natural polysaccharides against hepatitis B virus," World Latest Medicine Information, vol. 17, no. 20, 2017.

[89] L. Z. Feng, "Advances in extraction technology of Lentinan edodes," Guangdong Chemical, vol. 42, no. 13, pp. 138-139, 2015.

[90] G. Q. Zhang, M. R. Gai, and J. Z. Yang, "The recent efficacy observation of 62 cases of chronic B viral hepatitis was treated by lamivudine," The New Medicine, vol. 34, no. 4, pp. 239-240, 2003.

[91] Y.-M. Zhao, J.-m. Yang, Y.-h. Liu, M. Zhao, and J. Wang, "Ultrasound assisted extraction of polysaccharides from Lentinus edodes and its anti-hepatitis B activity in vitro," International Journal of Biological Macromolecules, vol. 107, Part B, pp. 2217-2223, 2018.

[92] M. Y. Meng, R. B. Huang, and H. Liang, "The inhibitory effects of polysaccharides from Hedyotis caudatifolia on hepatitis B virus," Pharmacology and Clinics of Chinese Materia Medica, vol. 35 , no. 4 , pp. $38-43,2019$. 
[93] X. D. Zhan, K. X. Wang, and C. P. Li, "Study on the antihepatitis B virus effect of snail polysaccharide in vitro," Chinese Journal of Experimental Traditional Medical Formulae, vol. 14, no. 3, pp. 66-68, 2008.

[94] L. F. Liu, "128 cases of chronic hepatitis B treated with polyporus polysaccharide and hepatitis B vaccine," Journal of Clinical Medicine, vol. 19, no. 6, pp. 15-16, 2009.

[95] S. F. Li, X. Wang, and X. E. Gui, "Effects of angelica polysaccharide on the functional status of dendritic cells HBC transgenic mice," Journal of Practical Diagnosis and Therapy, vol. 19, no. 5, pp. 313-317, 2005.

[96] X. Y. Liu, C. P. Li, and K. X. Wang, "Experimental study on polysaccharide of Cipangopaludina chinensis against HBV in vitro," China Journal of Chinese Materia Medica, vol. 38, no. 6, pp. 879-883, 2013.

[97] Q. F. Xia and H. L. Tan, "Experimental study on the anti - hepatitis b virus effect of polysaccharides from paniculate," Shandong Medical Journal, vol. 50, no. 7, pp. 44-45, 2010.

[98] X. L. Zhang, Y. D. Yang, C. B. Song, Z. H. Hu, and Y. P. Xu, "Synergy effect of oxymatrine on antiviral treatment of chronic hepatitis B," Chinese Journal of Nosocomiology, vol. 29, no. 17, pp. 2635-2638, 2019. 